\title{
A GUERRA FISCAL ENTRE OS ESTADOS MEMBROS DA FEDERAÇÃO EM RELAÇÃO AO ICMS: O PAPEL DOS TRÊS PODERES
}

Michele Cesar Espíndula

\section{INTRODUÇÃO}

A competência para instituição do Imposto sobre Operações relativas à Circulação de Mercadorias e sobre Prestações de Serviços de Transporte Interestadual e Intermunicipal e de Comunicação é dos Estados e do Distrito Federal, conforme determina o art. 155, II da Constituição Federal de 1988.

A Constituição também traz em seu art. $155, \$ 2^{\circ}$, XII, g, que cabe a lei complementar "regular a forma como, mediante deliberação dos Estados e do Distrito Federal, isenções, incentivos e benefícios fiscais serão concedidos e revogados". Nesta sistemática é necessária para concessão dos benefícios a celebração de convênio entre os estados, sendo este realizado no âmbito do Conselho Nacional de Política Fazendária - CONFAZ.

Entretanto os estados e o Distrito Federal não vêm respeitando a legislação vigente, concedendo por meio de leis ou decretos estaduais os benefícios fiscais de ICMS de forma unilateral, sendo esta a causa da guerra fiscal.

Essa prática traz grande insegurança jurídica e desafios que afetam a Federação em um todo, como: renúncia de vultosa receita pelos Estados e litígio entre os entes federados, demonstrando-se assim, um problema que desafia o Federalismo brasileiro.

O tema apresenta grande interesse por trata-se de uma questão complexa que ultrapassa os limites do campo do direito refletido diretamente na economia e 
•• Tributação, direitos fundamentais e desenvolvimento

política. Além disso, trata-se de um conflito de interesse que envolve os Estados, União e Municípios, assim como empresas e a sociedade como um todo.

Pretende-se analisar os principais aspectos relacionados à guerra fiscal travada pelos estados membros em relação ao ICMS, destacando o papel de cada um dos Três Poderes (Executivo, Legislativo e Judiciário) neste contexto, bem como a busca de soluções viáveis para o problema, mas que respeite os limites constitucionais impostos, com destaque a autonomia dos estados-membros.

\section{A GUERRA FISCAL NO CONTEXTO DO FEDERALISMO BRASILEIRO E ATRIBUIÇÕES DE COMPETÊNCIAS TRIBUTÁRIAS}

O Federalismo é a forma de estado adotado pelo Brasil desde a Constituição de 1891. Este nasceu com a Constituição norte-americana de 1787, baseando-se no ideal da criação de uma forma de estado que respeitasse e garantisse as coletividades políticas autônomas, consistindo a federação na união de coletividades regionais autônomas, os Estados Federados (SILVA, 2011, p. 99).

Para BULOS, (2014, p. 922), a Federação, trata-se de uma unidade dentro da diversidade. A unidade consiste na própria federação, enquanto a diversidade é inerente às partes que a compóem, isto é, os estados-membros, haja vista suas características próprias. A federação, portanto, é uma pluralidade de estados dentro da unidade que é o Estado Federal. Tal autor destaca as características comuns a uma federação:

- pacto entre unidades autônomas - a federação é uma aliança ou associação de Estados-membros autônomos, os quais integram o Estado Federal soberano;

- impossibilidade de secessão - uma vez criada, a federação não pode ser desfeita, mediante a retirada das unidades autônomas de poder que a integram, em virtude da indissolubilidade do vínculo federativo;

- extrai sua força da Constituição - o todo, o Estado Federal, e as suas partes indissociáveis, os Estados, retiram sua força da constituição, fome primária de rodas as competências administrativas, legislativas e tributárias, exercidas pelos governos locais;

- descentralização político-administrativa - na federação encontramos a primazia da descentralização político-administrativa, pois o poder central do Estado Federal é compartilhado com as entidades federadas, que exercem poderes autônomos;

- participação dos Estados no Poder Legislativo Federal - isto se dá por meio de deputados eleitos para elaborar leis de interesse nacional;

- órgão representativo dos Estados-membros - previsão, na Carta Magna, do Senado Federal, para representar as ordens jurídicas parciais, ou seja, os Estados federados; 
A guerra fiscal entre os estados membros da federação em relação ao ICMS •

- repartição de competências entre os entes federados - as entidades federativas podem gerenciar negócios (competência administrativa), ter renda própria (competência tributária) e criar comandos gerais e abstratos para reger suas relações (competência legislativa);

- possibilidade de intervenção federal - o objetivo dessa faculdade é preservar o equilíbrio federativo, nas hipóteses rigorosamente previstas na constituição;

- formação de Estados-membros - no modelo federativo existe a possibilidade de criação de novos Estados ou modificação dos já existentes, à luz das regras estabelecidas na constituição; e

- previsão de um órgão de cúpula do Poder Judiciário - é o caso do nosso Supremo Tribunal Federal, cuja tarefa precípua é guardar o Texto de 1988. (BULOS, 2014, p. 923).

O federalismo brasileiro nasceu de dentro para fora, no chamado movimento centrífugo, em razão da descentralização das antigas províncias do Estado unitário em unidades federadas autônomas (federalismo por segregação); diametralmente oposto às federações americana (1787), alemã (1871) e suíça (1848), que foram formadas de fora para dentro no movimento centrípeto do federalismo por agregação. Assim, nos Estados Unidos da América, os estados soberanos cederam parcela de sua soberania à União Federal, esta por sua vez, passou a deter poderes enumerados. Já os estados conservaram, a competências residuais, esse viés histórico, explica a maior autonomia dos estados norte-americanos em relação aos estados-membros brasileiros (SANTOS, 2008).

A doutrina classifica o federalismo, pelo critério da separação das atribuições de cada ente federativo, em integrativo, dual e cooperativo. No federalismo integrativo, temos a superioridade hierárquica da União Federal em relação aos estados-membros. Já o federalismo dual, se caracteriza pela separação bem delimitada das competências de cada ente federativo. Este foi o modelo seguido pelos EUA até a crise de 1929. Após, tal episódio histórico, e com o surgimento do Estado de Bem-Estar Social, o federalismo cooperativo, ganhou destaque, este, ao contrário do federalismo dual, não se caracteriza por uma divisão tão rígida de competências, sendo baseado na ideal de harmonização e cooperação entre as partes que compõem a federação. (SANTOS, 2008). O modelo de federalismo adotado no Brasil é o cooperativo.

Quanto à sistematização das repartições das competências constitucionais, o federalismo pode ser classificado em simétrico ou assimétrico. O federalismo simétrico se caracteriza pela busca do equilíbrio e da homogeneidade na repartição das 
-• Tributação, direitos fundamentais e desenvolvimento

competências dos entes. Já no federalismo assimétrico, há um distanciamento na homogeneidade tradicional, de forma a buscar a redução das desigualdades regionais (SANTOS, 2008).

A maior parte dos autores acredita que o Brasil adota o modelo simétrico, porém alguns autores defendem a ideia de que a Constituição de 88 adotou o federalismo assimétrico.

BULOS, (2014, p. 926) acredita que a o modelo brasileiro é do federalismo simétrico, entretanto, pondera que a Constituição traz em seu texto diversos preceitos de inspiração ao modelo assimétrico, inclusive aqueles de natureza tributária (CF, artigos 23; 43; 151, I; 155, 1, b, \$2 , VI e XII, $g$ ).

$\mathrm{Na}$ Constituição de 1988, o federalismo está estampado no artigo 1, "A República Federativa do Brasil, formada pela união indissolúvel dos Estados e Municípios e do Distrito Federal". A forma federativa foi protegida por cláusula pétrea no artigo $60, \$ 4^{\circ}$ inciso, I da $\mathrm{CRFB} / 88$, de modo que qualquer ato normativo tendente a aboli-la encontra-se eivado de inconstitucionalidade.

O Estado Federal brasileiro pode ser conceituado como o todo dotado de personalidade jurídica de Direito Público Internacional. Já a União é a entidade federal formada pela reunião das partes que compõem a Federação, tendo personalidade jurídica de direito público interno, a esta cabe o exercício das prerrogativas de soberania do estado brasileiro. Os estados-membros são entidades federativas componentes, dotadas de autonomia e de personalidade jurídica de Direito Público Interno (SILVA, 2011, p. 100). Dentro do Federalismo brasileiro ainda destaca-se o Distrito Federal que uma entidade político-administrativa, dotada de autonomia parcialmente tutelada pela União e os Município, que podem ser conceituadas como unidades geográficas divisionárias dos Estados-membros, possuindo personalidade jurídica de Direito Público Interno, e governo próprio, para administrar, descentralizadamente, serviços de interesse local (BULOS, 2014, p. 940 e 966).

O único titular de soberania é o Estado Federal, esta pode ser entendida como o poder supremo consistente na capacidade de autodeterminação plena não condicionada a nenhum outro poder externo ou interno (SILVA, 2011, p. 100).

Já os estados federados possuem apenas autonomia, ou seja, a capacidade de autodeterminação que deve ser exercido dentro do círculo de competências traçadas pela Constituição Federal (BARROSO, 2012, p. 171-172). 
Para Bulos, (2014, p. 934) a autonomia dos entes federados se exteriorizam por meio de quatro capacidades: capacidade de auto-organização: a capacidade do estado de estabelecer sua constituição própria (CRFB/88, art. 25, caput); capacidade de autolegislação: a capacidade do estado-membro de elaborar suas próprias leis que serão aplicadas em seu âmbito territorial, (CRFB/88, art. 25, caput); A capacidade de autoadministração: a capacidade que os estados têm de gerir seus negócios próprios, através das ações do governador, com base nas competências administrativas, legislativas e tributárias, previstas na Carta Magna (CRFB/88, art. 25, $\$ 1^{\circ}$ ). Dentro desta capacidade, destaca-se a competência tributária, haja vista que deverá ser garantido ao ente o mínimo de recursos necessários para a satisfação de suas necessidades básicas; por fim a capacidades de autogoverno: no qual os estados-membros devem organizar seu próprio governo, por meio de eleições de representantes dos Poderes Legislativo e Executivo, bem como organizar o poder Judiciário.

A autonomia pressupõe a garantia de competências próprias e exclusivas de cada ente federado (SERAFIN, 2014).

A ideia de autonomia é imprescindível no contexto da guerra fiscal, tendo em vista que, esta tem seu campo de incidência dentro dos limites traçados pela Constituição. Todo regramento ou ato de qualquer dos componentes do Estado federal que desrespeita os mandamentos constitucionais não pode ser classificado como exercício da autonomia, mas sim como arbítrio. Deste modo, não podem os estados-membros, a pretexto de agirem com a autonomia a estes assegurada, conceder benefícios fiscais de maneira diversa daquela prevista na Constituição Federal de 1988.

\subsection{Repartição de competências tributárias na Constituição brasileira de 1988}

No modelo de federalismo adotado pela Carta Magna, o federalismo cooperativo, a ideia de equilíbrio entre as unidade que compõem a Federação é essencial. Este equilíbrio deve ser respeitado na divisão de competências entre os entes federados.

Surgem assim, as chamadas competências federativas que são parcelas de poder atribuídas, pela soberania do Estado Federal, aos entes políticos, permitindo-lhes tomar decisões, dentro do exercício regular atividades, respeitando o círculo pré-traçado pela Constituição da República. (BULOS, 2014, p. 975). A atribuiç̧ão de competências tributárias, não foge a esta regra de equilíbrio que a Constituição de 1988 buscou instituir. 
-. Tributação, direitos fundamentais e desenvolvimento

Conforme orientação do Supremo Tribunal Federal, a Constituição do Brasil, ao institucionalizar o modelo federal de Estado, perfilhou, a partir das múltiplas tendências já positivadas na experiência constitucional comparada, o sistema do federalismo de equilíbrio, cujas bases repousam na necessária igualdade político- jurídica entre as unidades que compõem o Estado Federal (SERAFIN, 2014).

Neste contexto, TORRES, (2007, p. 6), destaca as duas principais características do sistema tributário federado, como a equidade existente entre os entes público, com respeito à distribuição equilibrada de recursos e a garantia da autonomia dos entes públicos menores para legislar e arrecadar os tributos de sua competência.

Para garantir a autonomia dos entes, a Constituição de 1988 elenca uma série de tributos que são de competência de cada um deles instituir.

Essa habilidade, atribuída ao ente político de instituir o tributo, com base em lei é a denominada capacidade tributária (SABBAG, 2014, p. 395-396).

Os artigos 153 a 156 da CRFB/88 cuidam da atribuição de competência tributária aos entes federados. Já a competência para legislar sobre direito tributário, que consiste em uma competência genérica para editar normas sobre o exercício do poder de tributar, está estampada no art. 24 da CRFB/88.

Brigadão, (2012) destaca as características da competência tributária:

(1a) Privatividade: retrata a exclusividade da pessoa política na instituição de sua competência. Quem detém a privatividade é somente a União, já que em algumas hipóteses ela poderá legislar sobre matérias de competência dos Estados e dos Municípios - Art. 154, I - regra de fechamento; Art. 154, II - mais que uma exceção, confirma a regra em caso de normalidade. Assim, como uma mesma matéria não poderá ser objeto de tributação por duas pessoas políticas diferentes, no cenário jurídico brasileiro não há que se falar em bi-tributação.

(2a) Indelegabilidade: configurando-se em um poder de legislar é, por essência, indelegável a competência tributária. Tal postulado fortalece a estruturação da repartição de competências no cenário jurídico brasileiro. O que se delega é a capacidade ativa de cobrança, arrecadação e fiscalização de tributos, o que não se confunde com a competência tributária. A primeira (capacidade ativa) retrata um poder administrativo enquanto a segunda (competência tributária) retrata um poder político.

(3a) Incaducabilidade: significa que a mesma não se encontra perdida pelo seu não exercício no decurso do tempo. A Lei Maior não delimita, em regra, lapso temporal para que o ente federativo exercite a sua competência tributária instituindo tributos. (...).

(4a) Inalterabilidade: A autonomia legislativa dada ao ente federado não tem o condão de alterar as diretrizes básicas traçadas na Constituição da República. A Lei Fundamental funcionará como uma espécie de moldura a que deve se adequar a lei infra- 
constitucional de cada ente; sob pena de invasão de competência, o que, por si só, macula o pacto federativo.

(5a) Irrenunciabilidade: Fica facultado ao ente federativo o exercício ou não de sua competência, mas dela não pode abrir mão por livre e espontânea vontade, a seu bel prazer, do contrário haveria o engessamento do Poder Legislativo ao deliberar sobre o tema em momento futuro (...).

(6a) Facultatividade: A Constituição não obriga aos entes federados exercitarem as suas competências. Assim, a pessoa política é livre para exercitar sua competência tributária, sendo que o não exercício da competência tributária não a transfere a outras pessoas políticas. Isso por que competência tributária não é res nullius, a competência tributária é privativa de cada pessoa política (artigo $8^{\circ}$ do Código Tributário Nacional). Assim, a competência tributária confere e delimita o poder e nada obsta a que o ente a exerça de forma parcial face ao traço da facultatividade. (...)

(7a) Intransferibilidade: Outro ente da federação até pode se beneficiar do repasse das receitas auferidas, mas é fato que a competência não se transfere para o mesmo, tendo em vista o fato de que não existe competência concorrente para instituir o tributo. $\mathrm{O}$ não exercício da competência, por si só, não tem o condão de transferi-la a outro ente da federação. Essa, pois, a dicção do disposto no artigo $8^{\circ}$ do Código Tributário Nacional: "o não exercício da competência tributária não a transfere a pessoa jurídica de direito público diversa daquela a que a Constituição a tenha atribuído.

$\mathrm{O}$ art. 153 da Constituição enumera os impostos federais, sendo estes de competência privativa da União, já o artigo 155 da CRFB/88, trata dos impostos estaduais, de competência privativa dos estados e do Distrito Federal. Os art. 156 e 147, parte final, cuidam dos impostos municipais, de competência privativa dos Municípios e do Distrito Federal (SABBAG, 2014, p. 399).

Em relação ao Imposto sobre Operações relativas à Circulação de Mercadorias e sobre Prestaçõos de Serviços de Transporte Interestadual e Intermunicipal e de Comunicação (ICMS), este está elencando no rol dos impostos estaduais (art. 155 da CRFB/88) sendo, portanto, imposto de capacidade dos estados-membros e do Distrito Federal de instituir. Sendo o ICMS o imposto ao qual recai os problemas relacionados à guerra fiscal.

\subsection{A guerra fiscal no Brasil}

A guerra fiscal pode ser entendida como um litígio existente entre os estados-membros e o Distrito Federal, em razão da concessão de forma unilateral de incentivos fiscais, de maneira diversa da estampada na Constituição Federal de 1988, ou seja, não respeitando os convênios entre as unidades federativas, regulamentado pela lei complementar n. 25 de 1975, que fora recepcionada pela Constituição, por força do art. 34, $\$ \$ 4^{\circ}$, e $5^{\circ}$ do ADCT (PAULSEN; MELLO 2012, p. 423). 
-. Tributação, direitos fundamentais e desenvolvimento

Esses incentivos podem ser concedidos de formas variadas, sendo por lei, decreto ou ato administrativo. Assim como, as vantagens nele consubstanciadas podem se apresentar de ordens diversas, Melo (2012, p. 369) destaca tais como fiscais, financeiras, creditícias, e operacionais que afetam a carga impositiva.

Os incentivos que podem ser concedidos são sintetizados por Paulsen; Mello, (2012, p. 424/425), como:

a) fiscais: isenção de imposto para novas empresas, sem produção similar no Estado, válida por determinado período de tempo; isenção ou redução do imposto para as micro e pequenas empresas, redução da alíquota do imposto para situações e produções especiais; postergação dos prazos de pagamento; isenção ou redução do imposto sobre produtos específicos destinados ao exterior;

b) financeiros: aquisição de ativos fixos; formação ou recomposição de capital de trabalho; financiamento do pagamento do imposto; participação acionária; financiamento para o desenvolvimento tecnológico; financiamento para empresas de turismo;

c) estímulo para infraestrutura: venda de lotes e galpões por preços reduzidos; permuta de terrenos para a localização de empresas; doação de áreas e lotes industriais; implantação de áreas e distritos industriais;

d) outros estímulos: facilidade no processo de registro de empresas; simplificação do processo de licitação para pequenas empresas; assistência técnica na elaboração do projeto; apoio à formação de capacitação de pessoal."

Tratando-se de um litigio entre os Estados, a guerra fiscal se demonstra um problema que desafia o Federalismo brasileiro.

Melo (2012, p. 372/374), destaca os problemas trazidos pela guerra fiscal. Este cita a consulta respondida pelo Conselho Administrativo de Defesa econômica (CADE), sobre a nocividade, ou não, à livre concorrência da concessão de benefícios fiscais, de forma unilateral pelos Estados.

$\mathrm{O}$ CADE adotou o seguinte entendimento:

1) A concessão de incentivos fiscais ou financeiro-fiscais possui o mesmo efeito para a empresa e para o mercado. Ambos esse tipos importarão na redução artificial do montante de imposto a pagar, gerando os mesmos efeitos seja para a empresa favorecida seja para os concorrentes e o mercado.

2) Benefícios concedidos no âmbito da "guerra fiscal", como visto numericamente, conferem vantagem dramática às empresas afetadas, podendo aumentar lucros em várias centenas de pontos percentuais.

3) Esse brutal favorecimento desnivela o campo em que se desenrola a dinâmica econômica, gerando diversos efeitos para a concorrência e o bem estar da coletividade, entre os quais: a) Retira o estímulo ao aumento constante do nível geral de eficiência da economia, permitindo uso menos eficiente de recursos e afetando negativamente a 
capacidade de geração de riquezas do país. b) Protege as empresas incentivadas da concorrência, mascarando seu desempenho, permitindo que mantenham práticas ineficientes e desestimulando melhorias na produção ou inovação. c) Permite que empresas incentivadas, ainda que auferindo lucros, possam "predatoriamente" eliminar do mercado suas concorrentes não favorecidas, mesmo que estas sejam mais eficientes e inovadoras, em função do enorme colchão protetor de que dispõem. d) Prejudica as demais empresas que, independentemente de sua capacidade, terão maiores dificuldades na luta pelo mercado, gerando com isso mais desincentivo à melhoria de eficiência e inovação. e) Gera incerteza e insegurança para o planejamento e tomada de decisão empresarial, dado que qualquer cálculo feito pode ser drasticamente alterado - e qualquer inversão realizada pode ser drasticamente inviabilizada com a concessão de um novo incentivo. f) Desestimula, por tudo isso, a realização de investimentos tanto novos quanto a expansão de atividade em andamento. É mais do que evidente, assim, que a guerra fiscal tem efeito altamente prejudicial à concorrência e danoso ao bem estar da coletividade.

4) A Constituição apresenta uma diversidade de objetivos e princípios que devem ser aplicados da forma mais harmônica possível. A livre concorrência e o bem estar geral constituem alguns deles, a ser compatibilizados com outros, igualmente legítimos, como o da redução das desigualdades regionais.

5) A decisão de conceder incentivos é prevista e aceita na Constituição, desde que determinada de formas específicas, as quais, ao menos formalmente, asseguraram que órgão concedente (a União ou os Estados por unanimidade no CONFAZ) sopese os diferentes interesses e princípios envolvidos, determine quais os incentivos, quais as regiōes beneficiadas e montantes adequados de forma a avançar ao máximo o princípio da redução das desigualdades regionais e afastando o mínimo necessário o outro.

6) Segundo o PNBE, os incentivos e benefícios no Brasil são concedidos à revelia das normas descritas acima, de forma que não se assegura a compatibilização constitucional mencionada, potencialmente violando o princípio da livre concorrência além do que seria justificável. Geram todos os efeitos negativos referidos acima, particularmente o de provocar insegurança, inibindo ou desestimulando ainda mais os investimentos, dado que a concessão imprevisível de incentivos altera radicalmente o mercado e pode mesmo tornar inviáveis inversões feitas após cuidadoso planejamento. Nesse sentido, o mero cumprimento da legislação atual já traria significativos benefícios para a coletividade.

7) Propostas que reduzam a possibilidade de guerra fiscal, ou que disciplinem a concessão de incentivos de forma previsível e segundo um sistema racional (definido pelas autoridades constitucionalmente competentes) podem contribuir para atenuar os danos hoje provocados por esta prática para o bem estar social e merecem pelas autoridades responsáveis uma cuidadosa atenção.

8) Dada a patente relação do tema com a defesa da concorrência, o CADE permanece passível de engajamento no debate, dentro evidentemente da sua esfera de competência legal, como evidenciada pela presente Consulta. (Consulta n. 38/99 - Rel. Cons. Marcelo Callari - j. 22.3. 2000 - DOU 1 de 28.4.2000, p. 1) 
•• Tributação, direitos fundamentais e desenvolvimento

Conforme se aufere a consulta 38/99 respondida pelo CADE acima exposta, a guerra fiscal traz uma série de problemas que de forma direta e indireta impactam a economia do país. Deste modo, este assunto se revela de grande importância prática ultrapassando os limites teóricos, bem como, o campo da Ciência do Direito.

Em grande parte dos países, o ICMS está inserido no imposto sobre valor agregado (ou adicionado), o denominado IVA, que é um imposto nacional. O IVA incide sobre as despesas e consumo e tributa o valor agregado nas transações efetuadas pelo contribuinte (ARAÚJO, 2011).

No direito comparado, percebe-se que muitos países unificam em um só imposto o ICMS (estadual), o IPI (federal) e o ISS (municipal), entretanto, preferiu-se adotar no Brasil a divisão em três impostos distintos para garantir a cada ente esta importante fonte de arrecadação (ALEXANDRE, 2013, p. 610).

Ocorre que o modelo nacional do IVA foi testado e aprovado em grande parte dos países do mundo, da mesma forma, o IPI por trata-se da parte federal do imposto não gera problemas no que tange a guerra fiscal. Entretanto, o mesmo não pode ser dito sobre as parte não nacionais do IVA no modelo brasileiro, ou seja, o ISS e principalmente o ICMS, o maior arrecadador nacional (ALEXANDRE, 2013, p. 610).

A Constituição de 1988, procurando evitar ou ao menos minorar a guerra fiscal estatuiu várias regras a respeito do ICMS. O legislador constitucional intencionava conferir uniformidade entre as diversas legislações dos estados e do Distrito Federal, bem como criar mecanismos para solucionar as controvérsias a respeito do sujeito ativo. Além disso, boa parte dos pontos maios polêmicos do ICMS foram delegados a regulamentação por meio de lei complementar nacional, (CRFB/88, art. $\left.155, \$ 2^{\circ}, \mathrm{XII}\right)$; adotou a celebração de convênios entre os entes como condição para que fossem concedidos e revogados os incentivos fiscais (CRFB/88, art. $155, \$ 2^{\circ}$, XII) e delegou ao Senado Federal as competências na fixação do regime de alíquotas do imposto, dentre outras regras de uniformização (ALEXANDRE, 2013, p. 610).

A técnica de prever a edição de lei complementar tributária para se prevenir conflitos entre os entes, tem a vantagem de evitar que os as normas seja facilmente revogadas pelo legislador ordinário, por outro lado, esta concentra a competência normativa no âmbito da União, o que acaba por enfraquecer o federalismo, ampliar litígios, e exaurir o Judiciário com demandas intermináveis (BULOS, 2014, p. 1437). 
A guerra fiscal entre os estados membros da federação em relação ao ICMS •

Alexandre (2013, p. 611) defende que a criação do IVA federal, com a extinção do ICMS, do IPI e do ISS resolveria, pelo menos em grande parte, os problemas trazidos pela guerra fiscal. Entretanto, este ressalva que, mesmo se garantindo o repasse integral dos recursos arrecadados, os estados e o DF não vão assentir na perda do poder político que o tributo representa nas negociaçôes para atrair investimentos aos seus territórios. Desta forma, essa solução se demonstra politicamente inviável.

Além disso, por mais que se reconheçam as vantagens do IVA federal, este não foi o modelo adotado pelo Brasil. Houve uma escolha política de se garantir aos estados a competência para instituição e arrecadação do ICMS. De modo que uma mudança nessa estrutura retiraria competências tributárias e a mais importante fonte de arrecadação destes entes, se demonstrando, portanto, totalmente contrária aos preceitos do Federalismo.

Assim, nos cabe analisar o direito posto, bem como mudanças neste, que poderiam ser realizadas, dentro do limite da autonomia dos entes federados, destacando, o papel dos Três Poderes (Executivo, Legislativo, Judiciário), para solucionar ou ao menos minorar o problema da guerra fiscal.

\section{O PAPEL DO PODER EXECUTIVO NA GUERRA FISCAL: A ATUAÇÃO DO CONFAZ}

O Poder Executivo se reveste de suma importância no contexto da guerra fiscal, sendo o entendimento desta passa pela compreensão de como os incentivos fiscais devem se regulamente concedidos bem como o funcionamento do Conselho Nacional de Política Fazendária.

\subsection{Sistemática para concessão de incentivos fiscais}

A Constituição de 1988 em seu artigo 155, $\$ 2^{\circ}$, XII, g, prescreve como devem ser concedidos os incentivos fiscais em relação ao ICMS, determinando que cabe a lei complementar "regular a forma como, mediante deliberação dos Estados e do Distrito Federal, isenções, incentivos e benefícios fiscais serão concedidos e revogados".

Assim, embora em regra, o instrumento competente para dispor sobre a isenção seja a lei ordinária, no que tange as isenções no âmbito do ICMS há previsão especial, conferindo à lei complementar a regulamentação destas (MELO, 2012, p. 367). 
-. Tributação, direitos fundamentais e desenvolvimento

Esta matéria foi regulamentada pela lei complementar 24/1975, recepcionada pela $\mathrm{CRFB} / 88$, por força do art. $34, \$ \$ 4^{\circ}$ e $5^{\circ}$ do Ato das Disposições Constitucionais Transitórias (ADCT). Por sua vez o $\$ 3^{\circ}$ do artigo citado, determinou que os incentivos fiscais concedidos anteriormente a Constituição deveriam ser reavaliados e reconfirmados no prazo de dois anos contados a partir da promulgação da CRFB/88 (MELO, 2012, p. 367).

Nesta sistemática, a LC 24/1975 determina que os incentivos fiscais apenas possam ser concedidos depois de passarem por deliberação do Conselho Nacional de Política Fazendária - CONFAZ, órgão formalmente inserido na Estrutura do Ministério da Fazenda, mas com assento garantido aos diversos titulares das fazendas estaduais (Secretários Estaduais da Fazenda ou cargo equivalente) (ALEXANDRE, 2013, p. 178).

Alexandre (2013, p. 178/179), sintetiza a sistemática para a concessão e revogação dos incentivos fiscais:

A matéria está regulada pela Lei Complementar 24/1975, segundo a qual a concessão de benefícios fiscais relativos ao ICMS dependerá sempre de decisão unânime dos Estados representados; a sua revogação total ou parcial dependerá de aprovação de quatro quintos, pelo menos, dos representantes presentes.

Dentro de 10 dias, contados da data final da reunião em que o convênio foi firmado, a resolução nela adotada será publicada no Diário Oficial da União. Após esse prazo, o Poder Executivo de cada Unidade da Federação disporá de 15 dias para publicar decreto ratificando ou não os convênios celebrados, considerando-se ratificação tácita dos convênios a falta de manifestação no prazo assinalado. Tais regras também se aplicam às Unidades da Federação cujos representantes não tenham comparecido à reunião em que hajam sido celebrados os convênios.

A não ratificação pelo Poder Executivo de todas as Unidades da Federação (no caso de concessão de benefício) ou de, no mínimo, quatro quintos das Unidades da Federação (no caso de revogação total ou parcial de benefício) implica rejeição do convênio firmado.

Até 10 dias depois de findo o prazo de ratificação dos convênios, deve ser publicada no Diário Oficial da União a informação relativa à ratificação ou à rejeição. Os convênios entrarão em vigor no trigésimo dia após tal publicação, salvo disposição em contrário, vinculando, a partir daí, todas as Unidades da Federação, inclusive as que, regularmente convocadas, não se tenham feito representar na reunião em que o ato foi celebrado.

Como se depreende da citação acima, a concessão regular dos incentivos fiscais trata- se de uma sequência de atos, com certo grau de complexidade e dependentes, em grande parte, da vontade política dos estados, sendo que esta, quase 
nunca, é movida por uma visão técnica que reflita sobre a necessidade ou não da concessão ou revogação de determinado incentivo.

Carraza (2007, p. 517), destaca que cabe aos Estados e o Distrito Federal, ratificar os convênios firmados. Essa ratificação se dá por meio de decreto legislativo, só após a aprovação do decreto os convênios que concedem a isenção passam a ter eficácia.

Carraza apud Borges, (2007, p. 520), ressalta que a ratificação é ponto terminal do processo legislativo, haja vista que o convênio trata-se de ato materialmente normativo, deste modo, a sua ratificação compete as Assembleias Legislativas Estaduais, e não ao Governador do estado. Após, a ratificação, as normas passam a valer no âmbito interno do estado, com o status de lei ordinária estadual (ou distrital) concessiva ou revogatória de isenção do ICMS.

A importância dos convênios é destacada por Carraza (2007, p. 524) com a citação do seguinte julgado do Supremo Tribunal Federal:

A celebração dos convênios interestaduais constitui pressuposto essencial a valida concessão, pelos Estados-membros ou Distrito Federal, de isenções, incentivos ou benefícios fiscais em tema de ICMS. Esses convênios - enquanto instrumentos de exteriorização formal do prévio consenso institucional entre as unidades federadas investidas de competência tributária em matéria de ICMS - destinam-se a compor os conflitos de interesses que necessariamente resultariam, uma vez ausente essa deliberação intergovernamental, da concessão, pelos Estados-membros ou Distrito Federal, de isenções, incentivos e benefícios fiscais pertinentes ao imposto em questão. $\mathrm{O}$ pacto federativo, sustentando-se na harmonia que deve presidir as relaçôes institucionais entre as comunidades políticas que compõem o Estado Federal, legitima as restrições de ordem constitucional que afetam o exercício, pelos Estados-membros e Distrito Federal, de sua competência normativa em tema de exoneração tributária pertinente ao ICMS. (ADI 1247-9, DJU 1, de 8.9.1995, p. 28.834).

Desta forma, o STF destaca a importância dos convênios aprovados no âmbito da CONFAZ, ressaltando que estes são essenciais para que se respeite o pacto federativo, sendo a manifestação da vontade de todos os Estados que compõem a Federação.

A exigência de deliberação do CONFAZ para concessão e revogação de incentivos fiscais, tem como louvável intenção, respeitar o princípio do Federalismo. Porém a exigência de unanimidade, para a aprovação do benefício, acabava por esvaziar sua finalidade, haja vista que se demonstra muito difícil o alcance de tal quórum, sendo natural que algum estado se sinta prejudicado com a concessão do incentivo. Isto por muitas vezes serve de argumento para que os benefícios sejam concedidos de maneira unilateral pelos estados, o que se demonstra prática totalmente contrária aos preceitos constitucionais vigentes. 
•• Tributação, direitos fundamentais e desenvolvimento

\subsection{Convênio ICMS 42/2016, a discussão sobre constitucionalidade e legalidade destes}

O país enfrenta uma crise econômica que acaba por reduzir a arrecadação. Dados do próprio CONFAZ demonstram que arrecadação do ICMS no Brasil diminuiu pelo terceiro mês consecutivo, culminando em redução de 17,3\% em comparação com o arrecadado entre janeiro e fevereiro de 2016 (ABREU; DALCIN, 2016).

Assim, muito influenciado pela crise financeira, foi aprovado no âmbito do CONFAZ em um primeiro momento, o Convênio ICMS 31, de 8 de abril de 2016, que estipulava a possibilidade dos estados determinarem o depósito de $10 \%$ dos benefícios num fundo de equilíbrio fiscal, porém em um segundo momento, foi editado o Convênio ICMS 42, de 3 de maio de 2016, que revogou expressamente o Convênio ICMS 31/16 (BRIGAGÃO, 2016).

O convênio $n^{\circ} 42$ autorizou que os Estados e o DF, reduzissem no mínimo, $10 \%$ todos os incentivos fiscais e financeiros, que acarretam a redução do ICMS (VIEIRA, 2016).

Tal redução pode ser dada se duas formas, conforme previsão dos incisos I e II, do convênio, in verbis:

Ficam os estados e o Distrito Federal autorizados a, relativamente aos incentivos e benefícios fiscais, financeiro-fiscais ou financeiros, inclusive os decorrentes de regimes especiais de apuração, que resultem em redução do valor ICMS a ser pago, inclusive os que ainda vierem a ser concedidos:

I - condicionar a sua fruição a que as empresas beneficiárias depositem no fundo de que trata a cláusula segunda o montante equivalente a, no mínimo, dez por cento do respectivo incentivo ou benefício; ou

II - reduzir o seu montante em, no mínimo, dez por cento do respectivo incentivo ou benefício.

Deste modo cabem aos estados e o Distrito Federal duas escolhas, ou reduzem de forma direta os incentivos, por meio de alteração do próprio ato normativo que os instituiu. Ou a redução pode ser feita de forma indireta, por meio da exigência feita ao contribuinte para que este realize o depósito de parte do valor do ICMS que deixou de ser recolhido aos cofres público em razão do benefício concedido (VIEIRA, 2016).

Esse depósito deverá ser realizado em um fundo de desenvolvimento e equilíbrio fiscal, nos moldes da cláusula segunda do convênio, in verbis: 
A guerra fiscal entre os estados membros da federação em relação ao ICMS

Cláusula segunda A unidade federada que optar pelo disposto no inciso I da cláusula primeira instituirá fundo de equilíbrio fiscal, destinado à manutenção do equilíbrio das finanças públicas, constituídos com recursos oriundos do depósito de que trata o inciso I da cláusula primeira e outras fontes definidas no seu ato constitutivo.

Os $\$ 1^{\circ}$ e $\$ 2^{\circ}$ do convênio 42 estabelecem as sanções para o caso de descumprimento dos itens I e II, vejamos:

$\$ 1^{\circ} \mathrm{O}$ descumprimento, pelo beneficiário, do disposto nos incisos I e II do caput por 3 (três) meses, consecutivos ou não, resultará na perda definitiva do respectivo incentivo ou benefício.

$\$ 2^{\circ} \mathrm{O}$ montante de que trata o inciso I do caput será calculado mensalmente e depositado na data fixada na legislação estadual ou distrital.

Faustino (2016) exemplifica a situação acima descrita:

A título de exemplo, se a partir de maio de 2016 o contribuinte que apure $\mathrm{R} \$ 100 \mathrm{mil}$ reais de ICMS, mas que, por um benefício concedido pelo Estado, recolha $\mathrm{R} \$ 80 \mathrm{mil}$ ( R\$ 20 mil de incentivo) deverá, mediante lei deste Estado, ou depositar R \$ 2 mil num fundo para continuar com o benefício, ou ter reduzido para $\mathrm{R} \$ 18$ mil o seu benefício.

Algumas considerações devem feitas em relação às disposições do convênio, haja vista sua duvidosa constitucionalidade e legalidade.

Conforme já destacado acima os convênios firmados no âmbito do CONFAZ, só passam a ter eficácia nos Estados e Distrito Federal, depois de sua ratificação, realizada com a aprovação do respectivo decreto legislativo.

Além disso, cabe a cada ente indicar o percentual de depósito, a redução que será utilizada, quais benefícios serão atingidos e quais as obrigações acessórias decorrentes (FERRAIOLI, 2016).

Assim, compreende-se que a existência do convênio bem como sua ratificação não são suficientes para que sejam aplicadas suas disposições (FERRAIOLI, 2016). Uma vez que, o STF tem firme posição no sentido que os convênios autorizativos, só produzem efeitos se os estados fizerem uso da autorização, sendo certo que o convênio 42 tem natureza autorizativa (ABREU; DALCIN, 2016).

Deste modo, só depois de aprovadas todas as medidas necessárias pelas Unidades Federadas, o convênio produzirá seus efeitos (ABREU; DALCIN, 2016).

Essas premissas destacadas são importantes haja vista a ponderação realizada por ABREU; DALCIN, (2016):

Isto posto, há de se enfrentar a possibilidade de tal Convênio, ao instituir referido depósito e a exemplo de outras recentes alterações introduzidas na legislação do 
-. Tributação, direitos fundamentais e desenvolvimento

ICMS, haver extrapolado os limites de sua competência e ter autorizado uma medida que na prática desrespeita termos e contratos negociados anteriormente junto aos Estados. Tal assertiva é difícil de ser negada nos casos de cobrança em relação a incentivos fiscais já concedidos por prazo determinado e mediante a realização de contrapartidas como geração de empregos, níveis mínimos de investimento em plantas produtivas e até mesmo contribuição de valores a outros fundos instituídos pelos Estados (estes sem lastro em Convênio CONFAZ). Nesse caso, há flagrante desrespeito ao artigo 178 do Código Tributário Nacional. (ABREU e DALCIN, 2016).

$\mathrm{O}$ art. 178 do CTN acima destacado refere-se o dispositivo que regulamenta a revogação das isenções, este expressamente afirma que, as isenções concedidas por prazo certo ou em função de determinadas condições não podem ser revogadas.

As isenções concedidas por prazo certo ou sob determinadas condições se revestem da característica do ato jurídico perfeito, sendo protegidas pelo art. 5\%, XXXVI, da Constituição Federal de 1988 (VIEIRA, 2016).

Portanto, se a empresa possui incentivo concedido nessas condições, fica vedado aos Estados alterá-los, seja por meio de alteração do ato normativo estadual que instituiu o benefício, seja por estipulação de depósito, em fundo específico, de parte do ICMS dado em benefício.

(...) A relação havida é bilateral e concernente às partes envolvidas. Reduzir o incentivo concedido viola ato jurídico perfeito anteriormente celebrado entre a empresa e o Estado, de modo a criar ônus fiscal sem amparo constitucional, além de romper com a segurança jurídica, princípio primordial ao Estado Democrático de Direito (VIEIRA, 2016).

Além dos problemas acima destacados, é preciso adentrar em outras aparentes inconstitucionalidades presentes no convênio 42 .

O referido cria a possibilidade de abertura de fundo de equilíbrio fiscal onde os contribuintes deverão realizar o depósito de parte do valor do ICMS que deixou de ser recolhido aos cofres público em razão do benefício concedido. Ocorre que o art. 167, IV, da CRFB/88 veda a vinculação de receita de impostos a órgão, fundo ou despesa (VIEIRA, 2016).

Assim, mesmo não tratando de fundo ligado a qualquer programa governamental em específico, é fato que a Constituição veda tal destinação a receitas provenientes de impostos (VIEIRA, 2016).

Além disso, as condiçõoes para a instituiçãao e funcionamento de fundos, é matéria reservada à lei completar nos moldes do art. 165, $\$ 9^{\circ}$, da Constituição de 1988 (BRIGAGÃO, 2016). 
A guerra fiscal entre os estados membros da federação em relação ao ICMS

Comentando sobre a inconstitucionalidade da criação do fundo, Brigagão (2016), destaca:

Houve, no passado, discussão sobre a extensão das consequências e efeitos decorrentes da desobediência dessa regra: se tal inobservância configuraria mero descumprimento das regras de Direito Financeiro (o que impediria tão somente que houvesse a afetação do valor cuja destinação específica se determinasse), ou se dela resultaria a própria inexigibilidade do tributo em si, cuja parcela fosse comprometida com a referida destinação.

A jurisprudência acabou por pacificar-se no sentido de que "a destinação específica contamina o próprio acréscimo", quando a ela vinculado desde a sua origem. Aplicando-se essa jurisprudência ao caso em exame, temos que será inconstitucional a própria incidência decorrente da revogação parcial promovida nos termos do Convênio ICMS $42 / 16$, e não somente a regra que determina o depósito do respectivo valor no "fundo de equilíbrio fiscal".

Outra situação correlata deve-se ao fato de que ao se destinar esses recursos a um fundo, a princípio, está se desrespeitando o mandamento estampado no art. 158, IV, da CRFB/88, que determina pertencem aos Municípios 25\% do produto da arrecadação do ICMS, tendo em vista que estes valores não serão repassados aos Municípios, exceto se a norma instituidora do fundo determinar que fosse realizada tal repartição (FERRAIOLI, 2016).

Outra situação trazida por VIEIRA (2016), deve-se ao fato de que, embora a autora destaca tratar-se de tema controvertido na jurisprudência, pode-se entender a redução de no mínimo $10 \%$ do incentivo fiscal, como majoração do tributo. Desta forma, deverá se respeitar o princípio da anterioridade, que veda a cobrança do tributo no mesmo exercício financeiro da lei instituidora, conforme determina o art. 150, III, $b$ da Constituição Federal de 1988.

Tendo em vista o Convênio 42 trata-se de uma disposição muito recente ainda não há jurisprudência ou doutrina consolidada sobre este. Deste modo surge a grande dúvida se este será aplicado aos incentivos fiscais concedidos unilateralmente pelos Estados, ou seja, os benefícios que não foram aprovados pelo CONFAZ.

Brigagão (2016) argumenta que sendo os benefícios concedidos unilateralmente, inconstitucionais, estes não produzem efeitos, assim, na visão deste não seria razoável pressupor que as regras do convênio se aplicam a estes tipos de incentivos. 
•• Tributação, direitos fundamentais e desenvolvimento

Por outro lado, Vieira (2016) e Abreu e Dalcin (2016), defendem que o Convênio 42 se aplica os benefícios concedidos de maneira unilateral pelos Estados, haja vista o próprio convênio não indicar qualquer distinção.

Por uma questão prática esta última corrente aparentemente se demonstra mais razoável, tendo em vista que a quantidade de benefícios concedidos de forma unilateral é muito superior a de incentivos concedidos no âmbito do CONFAZ, de forma que considerar que as disposiçôes do convênio 42 se aplicam apenas aos incentivos concedidos conforme determina a sistemática constitucional, acabaria reduzindo muito a aplicação deste.

Como se percebe do todo exposto o convênio ICMS no 42 , traz uma séries de disposições que poderão ser consideradas inconstitucionais e ilegais.

Os Estados não podem, a justificativa de atravessarem grave crise econômica desrespeitarem o ordenamento jurídico, sob pena de criarem um problema ainda maior, tendo em vista que se instituídos os convênios no âmbito dos estados, os contribuintes terão argumentos para questionarem a constitucionalidade e legalidade destes.

\subsection{A contribuição do Poder Executivo na guerra fiscal}

Percebe-se que o papel do Poder Executivo, destacado no presente pela atuação do CONFAZ, é de suma importância para a compreensão da guerra fiscal, assim como todos os poderes estes devem cumprir seu papel a fim de se encontrar uma solução satisfatória para o problema em destaque.

No que tange a que a dificuldade na concessão dos benefícios fiscais no âmbito do CONFAZ, por um lado podemos entender, que o componente da exigência de unanimidade, como um grande agravador da problemática. Pois, por mais que essa exigência tenha a intenção louvável de se respeitar o princípio do Federalismo, onde a vontade de um estado não pode sobrepôs-se a vontade dos outros, é inegável que esta acaba trazendo mais problemas do que soluções.

Entretanto, a dificuldade para a concessão regular do benefício, não pode servir como justificativa para o descumprimento dos preceitos estampados na Lei complementar $\mathrm{n}^{\circ} 24$, de 7 de janeiro de 1975, que regulamenta os convênios.

Sendo que, se houvesse o cumprimento integral do referido diploma normativo, de modo que os incentivos fiscais só fossem concedidos depois de aprovados nos convênios, não haveria mais guerra fiscal, de modo que com o cumprimento da lei, estaria findo tal conflito. 
A guerra fiscal entre os estados membros da federação em relação ao ICMS •

Porém, não parece que apenas a aprovação regular dos convênios resolveria todos os problemas relacionados à concessão de benefícios fiscais de ICMS. Veja-se que hoje a guerra fiscal é entediada como sendo o litígio existente entre os estados em razão da concessão de forma unilateral de incentivos fiscais. Ocorre que mesmo os convênios aprovados regularmente pela CONFAZ, podem trazer disposições que não se adequam os ditames constitucionais, o que acaba gerando grandes problemas.

Deste modo destaca-se o convênio ICMS n. 42/2015 que busca recompor a perdas trazidas pela concessão de incentivos fiscais, haja vista o momento de crise enfrentado pelo país, este fora regularmente aprovado, mas traz em seu texto uma série de questões que poderão ter sua constitucionalidade ou legalidade discutidas, portanto, uma série de possíveis litígios entre os contribuintes e os estados que acabarão, inevitavelmente, tendo que ser resolvidos pelo Judiciário.

Assim entende-se que mais uma vez os Estados utilizaram medidas de constitucionalidade duvidosa, na busca de recompor as receitas que eles mesmos abdicaram no momento da concessão dos benefícios fiscais, em que, na maior parte das vezes, foram concedidos de forma unilateral, ou seja, de maneira totalmente contrária da prevista na Lei Maior.

\section{O PAPEL DO PODER LEGISLATIVO NA GUERRA FISCAL}

\subsection{PL n. 240 de 2006, o fim da unanimidade para a aprovação dos convênios concessivos de incentivos fiscais}

Conforme destacado no capítulo acima, um dos causadores da guerra fiscal é a exigência de unanimidade para a aprovação dos convênios concessivos dos incentivos fiscais no âmbito do CONFAZ.

Sendo clara a dificuldade no alcance do quórum exigido pela LC 24/75, em seu art. $2^{\circ}, \$ 2^{\circ}$, in verbis: "A concessão de benefícios dependerá sempre de decisão unânime dos Estados representados; a sua revogação total ou parcial dependerá de aprovação de quatro quintos, pelo menos, dos representantes presentes".

Tendo em vista a dificuldade apresentada, seria necessário que as regras presentes no citado diploma fossem flexibilizadas, o que só seria possível por meio de uma alteração normativa.

Neste sentido destaca-se o projeto de lei completar $n^{\circ} 240$, de 2006, contendo a seguinte redação como ementa: 
•• Tributação, direitos fundamentais e desenvolvimento

\section{EMENTA:}

Altera a Lei Complementar n. 24, de 7 de janeiro de 1975, para que isenções, incentivos e benefícios fiscais relativos ao imposto sobre operaçōes relativas à circulação de mercadorias e sobre prestações de serviços de transporte interestadual e intermunicipal e de comunicação (ICMS) sejam concedidos por maioria qualificada ${ }^{1}$.

Tal projeto de lei visa facilitar o processo de concessão dos benefícios fiscais para que os estados e Distrito Federal passem a utilizá-los de maneira regular, conforme determina a Constituição e a legislação infraconstitucional.

Entretanto, algumas ponderações devem ser realizadas, em primeiro lugar trata-se de um projeto de lei, portanto dependente de vontade política para sua aprovação. Ocorre que mesmo na crise econômica vivida pelo país, não há sinalização de que este será aprovado, inclusive atualmente encontra-se arquivado desde o final da legislatura de $2014^{2}$.

Por outro lado, há quem defenda que não é a rigidez da LC 24/75 que leva os estados a concederem os benefícios fiscais de maneira unilateral. Deste modo, HARADA, (2012) destaca que o centralismo exercido pelo governo Federal faz com que pouco sobre para a atuação dos governos estaduais, assim os governadores acabam lançando mão de mecanismos tributários para atrair investimentos nos estados, pouco se importando com o agravamento das desigualdades regionais.

Apesar da importância o projeto, mesmo que em algum momento este venha a ser aprovado, fica claro que, pela complexidade do tema da guerra fiscal, outras medidas, inclusive legislativas, deverão ser tomadas para se chegar a uma solução satisfatória para o problema.

\subsection{O papel do Senado Federal na instituição das alíquotas do ICMS e a Resolução n. 22 de 1989}

O Senado Federal tem competência para editar resoluções em matéria tributária. Sendo este a Casa de representação dos estados e do Distrito Federal no Congresso Nacional exerce um importante papel de servir como foro para a discussão dos interesses destes (ALEXANDRE, 2012).

Disponível em: <http://www25.senado.leg.br/web/atividade/materias/-/materia/78731>. Acesso em: 2 nov. 2016.

2 Disponível em: <http://www25.senado.leg.br/web/atividade/materias/-/materia/78731>. Acesso em: 26 out. 2016. 
A guerra fiscal entre os estados membros da federação em relação ao ICMS ••

No que tange as resoluções relacionadas ao ICMS o Senado Federal possui três atribuiçôoes distintas. A primeira prevista no art. $155, \$ 2^{\circ}$, IV, da CRFB, que determina:

resolução do Senado Federal, de iniciativa do Presidente da República ou de um terço dos Senadores, aprovada pela maioria absoluta de seus membros, estabelecerá as alíquotas aplicáveis às operações e prestaçôes, interestaduais e de exportação.

As duas atribuições estão previstas no artigo $155, \$$ 2o, $\mathrm{V}$, $a$ e $b$ da CRFB/88, vejamos:

V - é facultado ao Senado Federal:

a) estabelecer alíquotas mínimas nas operações internas, mediante resolução de iniciativa de um terço e aprovada pela maioria absoluta de seus membros;

b) fixar alíquotas máximas nas mesmas operações para resolver conflito específico que envolva interesse de Estados, mediante resolução de iniciativa da maioria absoluta e aprovada por dois terços de seus membros.

Por força da resolução do Senado Federal n. 22 de 1989, a alíquota para a operação realizada entre estados está fixada em 12\%, com exceção das transações originadas das regióes Sul e Sudeste destinadas às regióes Norte, Nordeste e Centro-Oeste e ao Espírito Santo, que sofrem incidência de 7\%.

Deste modo, se a mercadoria é vendida na Região Nordeste para a Região Norte a alíquota total para o consumidor será de $17 \%$, mas $12 \%$ pertencerão ao local de produção, e 5\% ao local de consumo. O mesmo ocorreria se venda fosse realizada entre estados do Sul ou Sudeste. Já se a mercadoria for vendida da Região Sul para o Espírito Santo, da alíquota total de 17\%, 7\% pertence ao Estado produtor e $10 \%$ ao consumidor. Portanto, se o produto sai de uma região menos favorecida, a alíquota será sempre de $12 \%$ na origem e de $5 \%$ no destino. Saindo de uma região mais favorecida, pagará $7 \%$ na origem e $10 \%$ no consumo destinado ao Norte, Nordeste e Centro-Oeste e ao Espírito Santo, ou 12\% na origem e 5\% no destino de consumo para as Regiōes Sul e Sudeste (PAES, 2009).

Neste regime, há partilha na arrecadação entre o estado de origem e de destino. Portanto acaba se configurando um modelo híbrido de tributação utilizando-se tanto o princípio da origem quando o do destino.

Ocorre que a tributação na origem gera graves problemas, sendo um fator importante no entendimento da guerra fiscal.

Esse modelo de tributação faz com que os estados concedam os incentivos de maneira unilateral a fim de atrair as grandes empresas para o seu território. Como 
•• Tributação, direitos fundamentais e desenvolvimento

consequência os próprios estados abrem mão de vultosas receitas e viram reféns deste sistema enraizado de concessões irregulares de benefícios fiscais, na justificativa de que se um estado concede o outro também se torna obrigado a conceder.

Por outro lado, alguns setores como energia elétrica e combustíveis, sofrem exclusivamente tributação no destino, portanto estão imunes a concessão dos incentivos acimas descritos. Assim, mais uma vez o sistema híbrido, traz efeitos negativos, pois os setores que sofrem tributação no destino acabam se tornando alvos prediletos dos fiscos estaduais, incidido sobre estes, grande carga tributária (SALES, 2013).

Como exemplo Sales (2013), destaca “O setor elétrico responde por meros 2\% do PIB, mas a sua participação na arrecadação do ICMS excede 8,4\% - nível quatro vezes superior a sua participação no valor agregado." Sendo que a sobretaxa na energia elétrica prejudica a competitividade do país, haja vista trata-se de um insumo básico.

Diante do exposto percebe-se que o modelo de arrecadação de ICMS utilizado no Brasil, principalmente pela adoção do regime de tributação na origem, apresenta graves distorções, tanto do ponto de vista arrecadatório com sobretaxa em alguns setores, como do ponto de vista de fomento a guerra fiscal.

\subsection{Tributação no destino e a Emenda Constitucional 87/2015}

Conforme destacado o modelo de tributação na origem é um dos causadores da guerra fiscal. Desta forma, a adoção do princípio do destino se reveste como uma grande uma alternativa a fim de sanar o problema apresentado.

A adoção do princípio do destino significa que a arrecadação deve pertencer ao estado no qual ocorre o consumo. Lobato; Barrato (2007, p. 20/21) destacam as principais vantagens deste:

a literatura tem apontado que a receita dos impostos sobre bens e serviços deve ser apropriada (alocada, atribuída) pelo local onde ocorre o consumo final dos bens e serviços, de forma que a receita flua para os cofres da jurisdição em que o cidadão demanda serviços públicos;

é desejável que o cidadão (eleitor, consumidor) que mora em uma determinada jurisdição política pague impostos numa proporção correspondente aos serviços e bens públicos de que usufrui. Essa relação favorece a transparência e a responsabilidade fiscal;

além do vínculo entre o poder de tributação e o cidadão ser reforçado, o princípio de destino diminui a necessidade de criação de mecanismos de transferências compensa- 
A guerra fiscal entre os estados membros da federação em relação ao ICMS

tórias, para que as jurisdições possam exercer suas funções. Isso porque, em Federações, a adoção do princípio de destino, no que diz respeito à atribuição de receita oriunda das transações interestaduais, resulta numa distribuição horizontal (entre os estados) mais equitativa de receita, posto que o consumo é menos concentrado do que a produção;

o princípio jurisdicional interestadual resulta compatível com o adotado para as transaçôes internacionais; e

o princípio de destino elimina o motor da competição fiscal entre as jurisdições na forma predatória que caracteriza a guerra fiscal brasileira, ainda que outras modalidades específicas de competição fiscal possam vir a ser praticadas sob o princípio de destino.

Além disso, os autores afirmam que a guerra fiscal ajudou a esgotar os argumentos dos defensores do princípio da tributação na origem, haja vista a tributação no destino se montra superior, pois nesta não há transferência de crédito de um estado para outro, desobrigando o ente de reconhecer créditos presumidos que muitas vezes se demonstram fictícios. Do mesmo modo, a receita de um estado passa a ser compatível com o seu mercado consumidor, e não a base produtiva, trazendo por consequência maior justiça fiscal. Por fim torna mais visível a correspondência entre quem paga o imposto e quem recebe os serviços públicos (LOBATO; BARRATO, 2007, p. 21).

Sales (2013), por sua vez, afirma que o deslocamento da tributação da produção para o consumo, traria várias vantagens como: a harmonização das alíquotas entre os Estados e redução da tributação de insumos básicos como a energia elétrica, combustíveis e telefonia.

Pelo exposto percebe-se que a adoção do princípio do destino demostra inúmeras vantagens sem paralelo com a tributação na origem.

Inspirada pelas vantagens da tributação no destino bem como buscando dar um fim a uma longa disputa entre os Estados, recentemente foi promulgada a Emenda Constitucional n ${ }^{\circ} 87 / 2015$, que muda a sistemática na arrecadação do ICMS em compras realizadas pela internet e telemarketing, de modo que esta será gradualmente transferida do estado de origem para o estado de destino.

Germano (2015) esclarece como se dará a transição:

O novo texto torna gradual a alteração nas alíquotas, atribuindo aos estados de destino $100 \%$ da diferença de alíquotas em 2019. Até lá, vale a seguinte regra de transição: $20 \%$ para o destino e $80 \%$ para a origem (2015); $40 \%$ para o destino e $60 \%$ para a origem (2016); 60\% para o destino e $40 \%$ para a origem (2017); e $80 \%$ para o destino e $20 \%$ para a origem (2018). 
-. Tributação, direitos fundamentais e desenvolvimento

Já fora destacado que o ICMS interestadual incide quando determinado bem é produzido em um estado e vendido a outro, sendo o imposto devido em parte ao Estado de origem e em parte ao de destino.

Ocorre que essa regra é aplicada quando a operação mercantil é realizada entre contribuintes do ICMS. Entretanto, nas compras realizadas diretamente ao consumidor final, o imposto incidia apenas no estado de origem, aplicando-se alíquota interna como disposto no art. $155, \$ 2^{\circ}$, VII, “b” da CRFB/88, sendo que essa regra também se aplicava as vendas realizadas pela internet e telemarketing (BATISTA, 2012).

Batista (2012) ressalta que 64,75\% das sociedades empresárias que praticam o $e$-commerce estão localizadas na Região Sudeste, já a porcentagem de consumidores que utilizam os serviços de venda online, está melhor distribuída entre as Regiōes, representado 23\% na Região Sudeste, 12\% Nordeste, 19\% Norte, 19\% Centro-Oeste e $20 \%$ Sul.

Deste modo, a sistemática anteriormente utilizada apresentava uma grande injustiça fiscal, privilegiando apenas os estados onde há a grande concentração de sociedades empresárias que explora o e-commerce, ao detrimento dos Estados consumidores.

Diante de tamanha desigualdade, 19 estados brasileiros ratificaram o Protocolo ICMS 21/2011 (Acre, Alagoas, Amapá, Bahia, Ceará, Espírito Santo, Goiás, Maranhão, Mato Grosso, Mato Grosso do Sul, Pará, Paraíba, Pernambuco, Piauí, Rio Grande do Norte, Roraima, Rondônia e Sergipe e o Distrito Federal). Este protocolo disciplina a arrecadação do ICMS na venda de mercadorias realizadas pela internet e telemarketing. De modo que o Estado de origem do produto passa a ser sujeito passivo por substituição tributária, se responsabilizando pela retenção de parcela do ICMS devido ao Estado de destino (CARNEIRO, 2015).

Ocorre que no julgamento do Recurso Extraordinário n. 680.089/SE o STF declarou a inconstitucionalidade do protocolo, ao argumento de que este afrontava o art. $155, \$ 2^{\circ}$, inciso VII, alínea $b$, e inciso VIII, da CRFB/88, além disso, este tipo de repasse só poderia ser realizado com a edição de uma emenda constitucional, o que só veio a ocorrer com a Emenda 87/2015 (GERMANO, 2015).

\subsection{PEC/233 e a federalização do ICMS}

Tramita junto ao Congresso Nacional a Proposta de Emenda Constitucional 233/2008. A referida PEC, dentre outras medidas, propõe a revogação do inc. II, 
do art. 155 da CRFB/88 e a inclusão do Art. 155-A na Constituição Federal, visando profunda alteração na sistemática do ICMS, de modo que este passaria a contemplar uma competência conjunta entre União e Estados, de forma a mitigar a competência individual de cada estado para normatização do tributo. O imposto passaria a ser instituído por lei complementar nacional, e não mais por mais por 27 leis ordinárias estaduais (MAGALHĀES, 2012).

A última movimentação legislativa da PEC 233/2008 data de 11/03/2009, sendo que atualmente encontra-se na Comissão de Seguridade Social e Família (CSSF) da Câmara dos Deputados 3 .

SALAMACHA, (2013), afirma que existem diversos fundamentos constitucionais que possibilitam a federalização do ICMS entre eles destacam-se: o princípio da segurança jurídica que é não respeitado pela atual sistemática do imposto, haja vista a insegurança causada pela concessão de incentivos fiscais de maneira irregular que posteriormente acabam sendo questionados no Judiciário, de modo que a federalização retiraria a possibilidade dos estados concederem unilateralmente o incentivo; o princípio da livre concorrência, pois os benefício fiscais geram condiçōes totalmente discrepantes as empresas que o possuem; o direito a legislação tributária simplificada e clara, o autor defende que esse princípio decorre da segurança jurídica e da livre concorrência, sendo que o atual modelo de legislação tributária do ICMS apresenta grande complexidade que poderia ser drasticamente reduzida com a federalização deste.

O governo federal defende que a federalização do ICMS nos moldes estabelecidos pela PEC 233, traria uma grande simplificação na carga tributária, uma vez que vários tributos com incidência semelhante seriam unificados ao novo ICMS, sendo estes: a contribuição para o financiamento da seguridade social (Cofins), a contribuição para o Programa de Integração Social (PIS) e a contribuição de intervenção no domínio econômico relativa às atividades de importação ou comercialização de petróleo e seus derivados, gás natural e seus derivados e álcool combustível (CIDE-Combustível) (MAGALHĀES, 2012).

Além disso, argumenta-se que com a unificação das 27 legislações de ICMS em apenas uma legislação nacional, nos moldes do disposto no art. $155, \$ 5^{\circ}$ da PEC 233/2008, "O imposto terá regulamentação única, sendo vedada a adoção de

Informação do site da Câmara dos Deputados. Disponível em: <http://www.camara.gov.br/ proposicoesWeb/fichadetramitacao?idProposicao=384954>. Acesso em: 31 out. 2016 . 
•• Tributação, direitos fundamentais e desenvolvimento

norma estadual, ressalvadas as hipóteses previstas neste artigo" traria grande simplificação a este (MAGALHÃES, 2012).

Pela proposta contida na PEC, o ICMS passaria a se chamar IVA-E, e seria instituído conjuntamente através de lei complementar federal, de modo que não caberia mais aos estados legislar sobre este, as alíquotas seriam estabelecidas pelo Senado Federal. Cabendo à lei complementar específica do ICMS, a disciplina do processo administrativo, dispor sobre sanções penais a serem aplicadas aos estados, e sobre a criação de um novo modelo para o CONFAZ, sendo que este deverá ser presidido por um representante da União, e terá como atribuição a de editar o regulamento único do IVA-E, bem como fixar normas e prazos para o recolhimento do imposto e autorizar transação, anistia, remissão e moratória (MAGALHÃES, 2012).

Magalhães (2012) faz uma crítica à proposta para se acrescentar o art. 155-A a Constituição Federal, vejamos:

Art. 155, $₫ 3^{\circ}$ Relativamente a operações e prestações interestaduais, nos termos de lei complementar:

III - poderá ser estabelecida a exigência integral do imposto pelo Estado de origem, hipótese na qual:

a) o Estado de origem ficará obrigado a transferir o montante equivalente ao valor do imposto de que trata o inciso I ao Estado de destino, por meio de uma câmara de compensação entre as unidades federadas;

b) poderá ser estabelecida a destinação de um percentual da arrecadação total do imposto do Estado à câmara de compensação para liquidar as obrigaçôes do Estado relativas a operações e prestações interestaduais.

Este artigo fere visivelmente a cláusula pétrea do federalismo, porque privilegia o Estado de origem, que reterá o imposto do Estado de destino, circulando - ali - a riqueza que é produzida no Estado de destino, mesmo que por certo lapso de tempo, sem cobrança de quaisquer juros ou encargos financeiros, e de como o Estado de destino terá sua receita, efetivamente, paga. Isto gera insegurança de como o Estado de destino terá sua receita, deixando-o em situação inferior ao Estado de origem.

Como se percebe da citação destacada, mais uma vez há insistência com a adoção do princípio da origem, que conforme já destacado, é um dos grandes causadores da guerra fiscal, ora, uma reforma tributária deve levar em consideração as experiências já adotadas no país, a fim de solucionar os problemas apresentados, sob pena de estar fadada ao fracasso. 
A guerra fiscal entre os estados membros da federação em relação ao ICMS • •

Alecrim (2013) destaca que a PEC, afronta o princípio da subsidiariedade, pois está acentua a centralização de mais poderes na competência da União, retirando dos Estados autoridade constitucional para participar ativamente do processo de cooperação.

Por mais que o Brasil tenha adotado o modelo do federalismo cooperativo, em que os entes federados perdem uma parcela do seu poder de autoderminação na busca de uma integração da federação, esse modelo deve prever uma visão realista e equilibrada, caso contrário, irá atingir diretamente a autonomia dos entes federados, e, portanto desvirtuar o Federalismo (ALECRIM, 2013).

Deste modo, a proposta de federalização do ICMS vai de encontro com o Federalismo, pois fere a capacidade de autolegislação, autogoverno e autoadmiração dos Estados, sendo o poder decorrente limitado ao poder constituinte originário, não cabe a este o contrariá-lo (ALECRIM, apud DENARI, 2013).

Quando a Constituição Federal de 1988 estabeleceu que a o ICMS fosse um imposto de competência estadual, foi feita uma escolha política, assim, apesar das críticas que se faz ao modelo brasileiro, inclusive sendo ressalta a experiência positiva em outros países na instituição do imposto denominado IVA-nacional, esta não foi à escolha realizada pelo legislador originário.

Uma alteração tão drástica no ICMS, como se pretende através da PEC $233 / 2008$, em que pese às vantagens que esta pode trazer, não pode desrespeitar as competências tributárias que foram constitucionalmente atribuídas, sob pena de grave afronta ao princípio do Federalismo por suprimir a autonomia dos estados-membros. A aprovação da PEC 233, nos moldes que se encontra em tramitação no Congresso Nacional, viola a limitação material prevista no art. $60, \$ 44^{\circ}$, I da $\mathrm{CRFB} / 88$, sendo, desta forma, inconstitucional.

Assim, por mais desejável que seja o fim da guerra fiscal no Brasil, a solução para esta, por óbvio, deve respeito os ditames estampados na Carta Magna, caso contrário será criado um problema ainda maior.

Das medidas legislativas analisadas com finalidade de acabar com a guerra fiscal, aquela que parece apresentar mais viabilidade tanto do ponto de vista de se alcançar o objetivo quanto em relação ao respeito às regras constitucionais, é a da adoção do princípio do destino para a arrecadação do ICMS. Obviamente esta mudança teria que ser realizada de forma gradual a fim de torna possível o que se propõe. 
•• Tributação, direitos fundamentais e desenvolvimento

Ocorre que, como todos os outros projetos legislativos, este é dependente de grande vontade política para que possa ser aprovado. Sendo certo que tal mudança sofre rejeição dos estados mais industrializados do país, já que a princípio estes perderiam em arrecadação. Porém essa visão é reducionista, pois o fim da guerra fiscal geraria grandes benefícios para a Federação como um todo, de modo que se os Estados deixassem de conceder benefícios irregulares voltariam a possuir as receitas que vem abrindo mão ao longo de todos esses anos.

\section{O PAPEL DO PODER JUDICIÁRIO NA GUERRA FISCAL}

O Brasil adotou tanto o sistema de controle de constitucionalidade difuso, de inspiração norte-americana, como o concentrado de inspiração austríaca. Desta forma, pelo sistema difuso qualquer magistrado, diante de um caso concreto poderá averiguar a alegação de inconstitucionalidade. Já pelo modelo concentrado a análise da constitucionalidade é realizada em um órgão de cúpula, sendo que no caso do Brasil este órgão é o Supremo Tribunal Federal (BULOS, 2014 p. 193/198).

Essas premissas são importantes, haja vista que a concessão de forma unilateral dos benefícios fiscais seja por lei estadual ou por decreto, viola artigo $155, \S 2^{\circ}$, inciso XII, alínea "g", da Constituição Federal, portanto, são inconstitucionais, podendo assim ser declarados tanto de forma incidental por qualquer magistrado, ou de forma abstrata quando o STF é competente para o julgamento da ação, na forma do art. 103 da CRFB/88.

O Supremo Tribunal Federal, ao se deparar com as ações do controle concentrado tem por reiteradas vezes vem declarando a inconstitucionalidade das leis e decretos concessivos de benefícios fiscais que não foram aprovadas no âmbito do CONFAZ.

Destacando a visão do STF sobre o tema, (ALEXANDRINO; PAULO 2007, p. 220), ressaltam:

É clara a respeito a posição do STF, firmada no julgamento da ADIn 930, Rel. Min. Celso de Mello, segundo a qual "a concessão, mediante ato do poder público local, de isençôes, incentivos e benefícios fiscais, em tema de ICMS, depende, para efeito de sua válida outorga, de prévia e necessária deliberação consensual adotada pelo Estados-membros e pelo Distrito Federal, observada, quanto à celebração desse convênio intergovernamental, a forma estipulada em lei complementar nacional editada com fundamento no art. $155, \$ 2^{\circ}$, XII, “g”, da Carta Política. Este preceito constitucional, que permite à União Federal fixar padrões normativos uniformes em tema de exoneração tributária pertinente ao ICMS, acha-se teologicamente vinculado a um objetivo de nítido caráter político-jurídico: impedir a guerra tributária entre os Estados-membros e o DF”. 
A guerra fiscal entre os estados membros da federação em relação ao ICMS

Reforçando a posição acima, a Corte (ADIMC 1247, Rel. Min. Celso de Mello) já afirmou que "Os princípios fundamentais consagrados pela Constituição da República, em tema de ICMS: (a) realçam o perfil nacional de que se reveste esse tributo, (b) legitimam a instituição, pelo poder central, de regramento normativo unitário destinado a disciplinar, de modo uniforme, essa espécie tributária, notadamente em face de seu caráter não cumulativo, c) justificam a edição de lei complementar nacional vocacionada a regular o modo e a forma como os Estados-membros e o Distrito Federal, sempre após deliberação conjunta, poderão, por ato próprio, conceder e/ou revogar isençôes, incentivos e benefícios fiscais.” (Grifou-se).

E concluiu o Tribunal ensinando que "a celebração dos convênios interestaduais constitui pressuposto essencial para a válida concessão, pelos Estados-membros ou Distrito Federal, de isenções, incentivos ou benefícios fiscais em tema de ICMS" (ADIMC 1247).

Entretanto, essa firme jurisprudência da Corte não tem impedido que os estados e Distrito Federal continuem concedendo os benefícios de forma unilateral. Assim algumas razões parecem contribuir para este quadro ${ }^{4}$.

No julgamento da ADIn n. 709, da relatoria do Ministro Paulo Brossard, em 20 de maio de 1992, o Supremo Tribunal Federal firmou a tese de que "a revogação ou perda de vigência da norma impugnada constitui causa superveniente de perda de objeto da ação, com o consequente desaparecimento do interesse de agir do autor”.

Neste entendimento, aquele que apresentar seus direitos subjetivos lesados em razão das consequências advindas da vigência da norma deverá buscar reparação em ação própria nas vias ordinárias, haja vista não ter o controle concentrado o objetivo de tutelar direitos subjetivos (PÉRES, 2010).

Comentando sobre a adoção desta tese Péres (2010) destaca que esta produz consequências não desejáveis tais quais: a perpetuação de normas que muitas vezes são claramente inconstitucionais, assim como a possibilidade de retorno da norma, através do instituto da repristinação.

Abreu (2007) também argumenta contrário ao entendimento firmado pelo STF:

Toda vez que o tribunal proclama uma decisão nesses termos, e na sua maioria de forma monocrática, deixa de se pronunciar sobre o mérito da ação, ou seja, a constitucionalidade ou não do dispositivo não é analisada. Essa prática acaba configurando-se como uma verdadeira abdicação do exercício de sua função jurisdicional, que é,

STF, ADI 3.347-DF, Relator Min. Ayres Britto, data de julgamento 03.04.2012, data de publicação: DJE 11.04.2012. 
•• Tributação, direitos fundamentais e desenvolvimento

antes de tudo, afirmar e reafirmar a supremacia constitucional, não no sentido positivista, mas no sentido principiológico.

A preocupação quanto ao processamento e julgamento de uma ação direta de inconstitucionalidade deve ter, acima de tudo, um aspecto didático-pedagógico, deve resguardar a supralegalidade da Constituição e a segurança jurídica, como sendo o respeito aos direitos fundamentais e ao trato adequado da coisa pública.

Esse entendimento é aplicado no julgamento das ações relacionadas à guerra fiscal, como exemplo destaca-se o presente acordão:

Ação direta de inconstitucionalidade. Decreto n. 153-PR, de 16 de junho de 2000, editado pelo Governador do Estado do Espírito Santo. ICMS: concessão de crédito presumido. Liminar deferida pelo pleno desta corte. Revogação tácita. Perda de objeto.

1. O Decreto n. 1.090-R/2002, que aprovou o novo regulamento do ICMS do Estado do Espírito Santo, deixou de incluir no rol das atividades sujeitas a crédito presumido do tributo "as operaçôes internas e interestaduais com mercadoria ou bem destinados às atividades de pesquisa e de lavra de jazidas de petróleo e gás natural enquadradas no REPETRO", as quais eram objeto de impugnação na presenção de ação direta.

2. A jurisprudência desta Corte é pacífica quanto à prejudicialidade da ação direta de inconstitucionalidade, por perda superveniente de objeto, quando sobrevém a revogação da norma questionada. Precedentes.

3. Ação direta de inconstitucionalidade julgada prejudicada em razão da perda superveniente de seus objeto". ${ }^{5}$ (grifos meus).

Quando os Estados têm os atos normativos concessivos dos benéficos fiscais questionados pelas ações do controle concreto, estes cientes da jurisprudência do STF, em muitas das vezes, revogam o ato normativo, de modo que a ação proposta perca o objeto, e voltam, posteriormente, a conceder o mesmo incentivo por meio de outra norma estadual.

Por outro lado, quando o ato normativo concessivo do benefício fiscal chega a ser julgado e declarado inconstitucional pelo Supremo é comum que este utilize a técnica de modulação dos efeitos temporais da decisão.

Bulos (2014, p. 367/368) esclarece que o princípio da modulação temporal dos efeitos do controle concentrado de normas permite que o Supremo Tribunal Federal manipule ou gradue os efeitos de sua sentença podendo restringir ou limitar os efeitos temporais da declaração abstrata de inconstitucionalidade. Esta modulação permite entre outras situações, dosar os efeitos retroativos (ex tunc) da decisão.

STF, ADI: 2.352-ES, Relator Min. Dias Toffoli, data de julgamento 01.06.2011, data de publicação 29.08.2011. 
A guerra fiscal entre os estados membros da federação em relação ao ICMS • •

A Lei 9.868 de 10 de novembro de 1999 que dispõe sobre o processo e julgamento da ação direta de inconstitucionalidade e da ação declaratória de constitucionalidade perante o Supremo Tribunal Federal regulamenta tal instituto em seu artigo 27, in verbis:

Art. 27. Ao declarar a inconstitucionalidade de lei ou ato normativo, e tendo em vista razões de segurança jurídica ou de excepcional interesse social, poderá o Supremo Tribunal Federal, por maioria de dois terços de seus membros, restringir os efeitos daquela declaração ou decidir que ela só tenha eficácia a partir de seu trânsito em julgado ou de outro momento que venha a ser fixado.”

Nas decisões relacionadas aos benefícios fiscais concedidos de forma unilateral é comum que o Supremo em nome da segurança jurídica, module os efeitos desta. Como exemplo destaca-se o acordão abaixo transcrito, em que o STF declara a inconstitucionalidade de lei do Estado do Paraná que concedeu benefício fiscal de forma irregular, mas modula os efeitos para a data a partir do julgamento:

Ementa: I. TRIBUTÁRIO. LEI ESTADUAL QUE INSTITUI BENEFÍCIOS FISCAIS RELATIVOS AO ICMS. AUSÊNCIA DE CONVÊNIO INTERESTADUAL PRÉVIO. OFENSA AO ART. 155, \$2º, XII, $g$, DA CF/88. II. CONTROLE DE CONSTITUCIONALIDADE. MODULAÇÃO DOS EFEITOS TEMPORAIS. 1. A instituição de benefícios fiscais relativos ao ICMS só pode ser realizada com base em convênio interestadual, na forma do art. 155, $\$ 2^{\circ}$, XII, $g$, da CF/88 e da Lei Complementar n. 24/75. 2. De acordo com a jurisprudência do STF, o mero diferimento do pagamento de débitos relativos ao ICMS, sem a concessão de qualquer redução do valor devido, não configura benefício fiscal, de modo que pode ser estabelecido sem convênio prévio. 3. A modulação dos efeitos temporais da decisão que declara a inconstitucionalidade decorre da ponderação entre a disposição constitucional tida por violada e os princípios da boa-fé e da segurança jurídica, uma vez que a norma vigorou por oito anos sem que fosse suspensa pelo STF. A supremacia da Constituição é um pressuposto do sistema de controle de constitucionalidade, sendo insuscetível de ponderação por impossibilidade lógica. 4. Procedência parcial do pedido. Modulação para que a decisão produza efeitos a contatar da data da sessão de julgamento ${ }^{6}$. (Grifos nossos).

Considerando que a regra adotada no Brasil é a declaração de nulidade, ou seja, os efeitos da declaração de nulidade produzem efeitos ex tunc (retroativos), a aplicação da modulação dos efeitos da decisão deve ser feita com ponderação, haja vista seu caráter de excepcionalidade. Entretanto para (GALLINA; BOSSOLI, 2009) “a jurisprudência do Supremo Tribunal Federal tem caminhado para a

6 STF, ADI 4.481-PR, Relator Min. Roberto Barroso, data de julgamento 11.03.2015. 
•• Tributação, direitos fundamentais e desenvolvimento

adoção da restrição dos efeitos temporais em matéria tributária como regra, sem observar o seu caráter excepcional”.

Os estados ao concederem os benefícios fiscais de forma unilateral tem plena ciência de que estão agindo de maneira contrária ao que determina a Constituição Federal, entretanto isto não impede que estes instituam os atos normativos.

Quando o STF utiliza a técnica da modulação dos efeitos da decisão nos julgamentos relacionados à guerra fiscal, em que pese à necessidade do respeito à segurança jurídica, acaba por garantir que uma lei sabidamente inconstitucional acabe por produzir efeitos até determinado momento, sendo que os efeitos desta decisão geram uma perda enorme de recursos públicos, haja vista a isenções do ICMS representarem uma vultosa renúncia de receitas praticada pelos estados.

Assim percebe-se que pela sistemática apresentada, no que tange a guerra fiscal, o STF não vem cumprindo plenamente seu papel de Guardião da Constituição.

\subsection{Decisão proferida no Processo n. 0334903-24.2016.8.19.0001: a proibição do Estado do Rio de Janeiro de conceder novos incentivos fiscais}

Em recente decisão de natureza liminar, proferida na ação popular de Processo n. 0334903-24.2016.8.19.0001, na data de 26/10/2016, o juiz Marcelo Martins

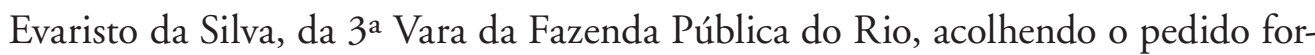
mulado pelo Ministério Público, proibiu que o estado do Rio de Janeiro concedesse, ampliasse ou renovasse benefícios fiscais ou financeiros até a apresentação, em 60 dias, de um estudo do impacto orçamentário-financeiro de todos os incentivos já concedidos.

Além disso, no mesmo prazo deverá ser encaminhada ao juízo a relação das empresas beneficiadas pelos incentivos fiscais e financeiros (concedidos sob a forma de créditos tributários futuros). Por fim o estado deverá enviar a $3^{\mathrm{a}}$ Vara da Fazenda Pública todas as Cartas-consultas das sociedades empresarias que receberam incentivos fiscais, na forma do art. $5^{\circ}$ da Lei 4.321/04 que regulamenta a concessão de incentivos fiscais no estado do Rio de Janeiro, in verbis:

As empresas interessadas na obtenção dos benefícios relacionados no art. $1^{\circ}$ desta Lei deverão apresentar, à Secretaria Executiva da Comissão de Avaliação de Incentivos Fiscais - CAIF, a que se refere o art. $8^{\circ}$, Carta-Consulta contendo informações detalhadas sobre o projeto a ser desenvolvido. 
Também deverão ser enviados todos os documentos e vistorias comprobatórias de que as sociedades empresárias cumpriram os requisitos/contrapartidas, previstos nessa mesma legislação?.

Em sua decisão o juiz destacou os fundamentos do pedido realizado pelo Ministério Público, vejamos:

i) a maioria dessas isenções tributárias não foi feita através do CONFAZ;

ii) a ausência de órgão central para realizar controle e acompanhamento dos incentivos;

iii) não são acompanhadas de um processo administrativo de controle, que permita avaliar a necessidade de renovação e os efeitos dos incentivos na economia;

iv) não são objetiva, clara e corretamente previstas na legislação orçamentária, tanto na LOA (art. 5º, II da LRF), quanto na LDO (art. $4^{\circ}, \$ 2^{\circ}, \mathrm{V}$ da LRF);

v) não são acompanhadas da indispensável condição de validade que lhe autoriza a existência, qual seja, previsão e real implementação de medidas compensatórias que lhe façam frente (leia-se: aumento de receita proveniente da elevação de alíquotas, ampliação da base de cálculo, majoração ou criação de tributo ou contribuição), na forma do art. 14 , II e $\$ 3^{\circ}$ da LRF;

vi) não houve sequer estimativa séria e individualizada de impacto orçamentário-financeiro nas metas fiscais no exercício em que devessem entrar em vigor e nos dois seguintes, tal como determina o caput do art. 14 da LRF. Apenas se alegava genericamente a expectativa de promessa de crescimento da economia, sem que se comprovassem a ausência, de fato, de comprometimento das metas fiscais, dentre outras irregularidades ${ }^{8}$.

Além disso, o magistrado destaca que apesar da crise financeira vivida o estado do Rio de Janeiro continua ampliado a política de renúncia de receitas através da concessão de incentivos fiscais, ao mesmo tempo em que contingencia despesas nos quatro maiores campos de atuação dos direitos fundamentais sociais: saúde, educação, assistência social e segurança pública (fls. 02).

Outro fundamento utilizado na decisão foi o art. 11, caput da lei complementar n. 101/2000, in verbis: "constituem requisitos essenciais da responsabilidade na gestão fiscal a instituição, previsão e efetiva arrecadação de todos os tributos da competência constitucional do ente da Federação". Deste modo este pondera que, por mais que o dispositivo não impeça a concessão de incentivos na busca do desenvolvimento econômico e social da região, este instrumento não pode ser manejado de forma livre pelos poderes Executivo e Legislativo (fls. 02/03).

Notícia vinculada no site do TJ/RJ. Disponível em: <http://www.tjrj.jus.br/web/guest/ home/-/noticias/visualizar/40704>. Acesso em: 10 nov. 2016.

8 Disponível em: <http://d2f17dr7ourrh3.cloudfront.net/wp-content/uploads/2016/10/liminar.pdf >. Acesso em: 10 nov. 2016. 
-. Tributação, direitos fundamentais e desenvolvimento

A LC n. 101/2000, em seu art. 14 exige para a concessão ou ampliação de incentivo ou benefício de natureza tributária que seja procedida à estimativa de impacto orçamentário- financeiro destes. No estado do Rio de Janeiro tal estudo deveria ser realizado pela Superintendência de Tributação - órgão vinculado a Subsecretaria de Receita, da Secretaria de Estado de Fazenda -, na forma do art. 6, inciso XVIII, "c", do Decreto Estadual n. 40.613/2007 e do art. 83 da Resolução SEFAZ n. 45/2007. Entretanto, o Tribunal de Contas do Estadual TCE/RJ em sede de auditorias realizadas na Secretaria de Fazenda, conclui que muitos dos atos concessivos de benefícios fiscais - principalmente aqueles editados mediante Decretos do Chefe do Poder Executivo - sequer passam pelo crivo da Superintendência de Tributação e, destarte, não se submetem à sua análise prévia, o que inviabiliza a realização de estudo de impacto orçamentário-financeiro (fls. 07).

Outro problema destacado pelo TCE/RJ deve se ao fato de que para a concessão ou ampliação de incentivos fiscais que acarretem renúncia de receita, a lei de reponsabilidade fiscal (LC 101/2000), exige em seu art. 14, incisos I e II, a que sejam observadas pelo menos uma das seguintes condições: a) o renunciante deve demonstrar que a renúncia foi considerada na estimativa de receita da lei orçamentária, e não afetará as metas previstas na própria lei de diretrizes orçamentárias; b) seja especificado que a renúncia será acompanhada de alguma compensação, seja elevação alíquotas, ou criação de novos tributos (fls. 08).

O juiz destaca a estimativa de receita que esta só pode ser efetivada com uma gestão planejada, responsável e transparente. Uma vez que a previsão da renúncia será dependente de que estimativas das receitas prevista na LOA venham corresponder à realidade, o que não vem acontecendo no estado do Rio de Janeiro segundo dados do próprio TCE/RJ ${ }^{9}$. Diante desta situação torna-se muito difícil dimensionar adequadamente o impacto financeiro da concessão dos incentivos fiscais (fls. 09).

O Ministério Público argumentou que as renuncias de receita cresceram acima da meta estabelecida na LOA no exercício 2014/2015, segundo dados do sistema DUB-ICMS, foi renunciado no ano de 2014 R \$ 7.422.890.570,00 já no ano de 2015 o valor é de $\mathrm{R} \$ 9.318 .710 .499,00$. Este conclui que principalmente devido

Em 2015 a previsão de decréscimos das receitas prevista na LOA foi da ordem de R \$ 20 bilhões (fls. 9). 
diminuição do crescimento econômico regional, o planejamento fiscal realizado pelo Rio de Janeiro, não apresenta a transparência nem a responsabilidade exigida pela LRF (fls. 10).

O magistrado destaca a Lei Estadual n. 7428, de 25/08/2016, que cria o Fundo Estadual de Equilíbrio Fiscal - FEEF condicionando a "fruição de benefício fiscal ou incentivo fiscal, já concedido ou que vier a ser concedido", ao depósito no fundo do "montante equivalente ao percentual de $10 \%$ (dez por cento) aplicado sobre a diferença entre o valor do imposto calculado com e sem a utilização de benefício ou incentivo fiscal concedido à empresa contribuinte do ICMS” (art. 2o ${ }^{10}$ (fls. 11).

Essa lei veio regulamentar o convênio ICMS 42/2016, já analisado no capítulo 2 do presente.

Para o juiz Marcelo Martins Evaristo da Silva a referida lei apresenta os seguintes vícios:

(i) inovação de matéria constitucionalmente reservada à lei complementar federal (art. 163, I e V da CRFB); (ii) inobservância do prazo mínimo fixado na Lei Complementar n. 101/2000 para a medida compensatória - exercício em que se inicia a vigência do benefício e nos dois seguintes; e (iii) ampliação das formas de compensação, ao arrepio da disciplina da Lei de Responsabilidade Fiscal e com potencial prejuízo à fiscalização e ao cumprimento das metas. Quanto a este último ponto, impende assinalar que o Tribunal de Contas da União já teve a oportunidade de rechaçar a interpretação ampliativa das medidas compensatórias de renúncia de receitas previstas no art. 14, II da LC n. 101/2000, inclusive a utilização específica de excesso de arrecadação, como preconizado no art. $3^{\circ}$ da Lei Estadual n. 7428/2016 11

Pelo exposto bem como pelas outras razões trazidas pelo magistrado em sua decisão percebe-se o quanto esta foi bem fundamentada. Entretanto, é preciso destacar que se trata de uma decisão interlocutória, portanto, não definitiva.

Para justificar a urgência da decisão foi ressaltado que mesmo vivendo um período de crise financeira o estado do Rio de Janeiro concedeu ou renovou nos meses de junho e agosto 50 novos benefícios fiscais, sendo que na visão do magistrado essa atitude demonstra a violação ao princípio da proporcionalidade, na sua vertente de vedação à proteção eficiente de direitos fundamentais sociais, haja vista a diminuição das receitas para a aplicação nas áreas como a saúde e educação (fls. 23).

10 Disponível em: <https://www.legisweb.com.br/legislacao/?id=327936>. Acesso em: 17 nov. 2016.

11 Disponível em: <http://d2f17dr7ourrh3.cloudfront.net/wp-content/uploads/2016/10/liminar.pdf>. Acesso em: 10 nov. 2016, fls. 11. 
•• Tributação, direitos fundamentais e desenvolvimento

Ocorre que por mais louvável que seja a decisão do magistrado, sendo apoiada em argumentos técnicos e não meramente políticos, esta por óbvio se restringi a Estado do Rio de Janeiro no qual o juízo exerce sua jurisdição.

Deste modo, apenas um Estado da Federação fica proibido de conceder os benefícios sendo certo que praticamente todos os outros estados também os instituem de maneira irregular. Portanto seria necessária uma proibição a nível nacional para que não fosse gerada uma desigualdade entre os estados-membros, desigualdade esta, totalmente incompatível com o Princípio do Federalismo estampada na Constituição Federal.

\subsection{Proposta de súmula vinculante n. 69: a proibição de concessão dos incentivos fiscais de forma irregular a nível nacional}

$\mathrm{O}$ instituto da súmula vinculante foi introduzido no direito brasileiro por meio da Emenda Constitucional n. 45/2004 que acrescentou o art. 103-A a Constituição Federal 1988.

Por meio desta o STF pode dar padrão à exegese de uma norma jurídica da qual existe controvérsia, em nome da segurança jurídica. As súmulas vinculantes apresentam eficácia irrestrita (erga omnes) e efeitos vinculantes aos órgãos do poder Judiciário e Administração Pública direta e indireta (BULOS, 2014, p. 1334).

A competência para criação da súmula vinculante compete exclusivamente ao Supremo Tribunal Federal que poderá, por ofício ou provocação, mediante decisão de 2/3 dos Ministros e depois de reiteradas decisóes sobre matéria de natureza constitucional, aprovar súmula que a partir de sua publicação na impressa oficial, passará ater efeitos vinculantes os órgãos do poder Judiciário e Administração Pública direta e indireta, também compete ao STF proceder à revisão e o cancelamento destas, nos moldes estabelecidos em lei ordinária federal (CRFB/88, art. 103-A, caput) (BULOS, 2014, p. 1335).

Para a criação da súmula vinculante é necessário que se preencha os dois requisitos trazidos pelo art. 103-A $\$ 1^{\circ}$, aos quais: a existência de controvérsia atual entre órgãos judiciários ou entre estes e a Administração Pública que acarrete grave insegurança jurídica e relevante multiplicação de processos sobre questão idêntica (BULOS, 2014, p. 1335).

Pelo que fora analisado até agora a criação de uma súmula vinculante em relação à concessão irregular de incentivos fiscais parece atender todos os requisitos exigidos pela Carta Magna. 
A guerra fiscal entre os estados membros da federação em relação ao ICMS •

Desta forma o Ministro Gilmar Mendes apresentou a seguinte proposta de súmula vinculante, a PSV 69:

Qualquer isenção, incentivo, redução de alíquota ou de base de cálculo, crédito presumido, dispensa de pagamento ou outro benefício fiscal relativo ao ICMS, concedido sem prévia aprovação em convênio celebrado no âmbito do CONFAZ, é inconstitucional.

Nos termos da ementa apresentada qualquer incentivo fiscal de ICMS concedido de forma irregular será considerado inconstitucional.

A aprovação da súmula seria de grande importância ao combate à guerra fiscal, principalmente em razão do instituto da reclamação, este é o instrumento previsto na Constituição para garantir a eficácia das súmulas vinculantes, nos moldes do art. 103-A, $\$ 3^{\circ}$, in verbis:

Do ato administrativo ou decisão judicial que contrariar a súmula aplicável ou que indevidamente a aplicar caberá reclamação ao Supremo Tribunal Federal que, julgando-a procedente, anulará o ato administrativo ou cassará a decisão judicial reclamada, e determinará que outra seja proferida com ou sem a aplicação da súmula, conforme o caso.

O procedimento da reclamação, ao contrário das ações do controle concentrado de normas, é célere. Assim Funaro (2014) argumenta que os atos administrativos e judicias que contrariarem a súmula poderão ser cassados de forma rápida e direta pelo STF. Além disso, este afirma que serão potencializados os riscos de serem pessoalmente responsabilizados os governadores e secretários dos estados pela concessão e até manutenção dos incentivos fiscais irregulares, podendo inclusive ser afetados seu patrimônio liberdade e direitos políticos, o que incentivaria a revogação dos benefícios anteriormente concedidos.

$\mathrm{Na}$ visão do autor sendo aprovada a súmula vinculante 69 os administradores poderão anular qualquer benefício fiscal concedido à revelia do CONFAZ, nos moldes determinados pelas súmulas 346 e 473 do STF. Este ressalva que embora se deva respeito ao devido processo legal e a garantia aos direitos individuais decorrentes de situações jurídicas consolidadas é provável que sejam cobrados dos beneficiários dos incentivos irregulares os valores que deixaram de ser recolhidos aos cofres públicos, pois nos moldes do artigo 142, parágrafo único, do CTN, sob pena de responsabilidade funcional do servidor, é defeso a este homologar pagamento realizado a menor (FUNARO, 2014).

Por fim Funaro (2014), destaca que o descumprimento voluntário da súmula vinculante por parte dos servidores poderia resultar em processos tanto na via ad- 
•• Tributação, direitos fundamentais e desenvolvimento

ministrativa quanto na via judicial, civil e criminalmente por dano ao patrimônio público. Podendo estes ser propostos tanto pelo Ministério Público, como pelo cidadão eleitor por meio do instrumento da Ação Popular.

Considerando a jurisprudência do STF acerca da modulação dos efeitos temporais da decisão em relação aos julgamentos das ações do controle concentrado que se discute sobre benefícios fiscais concedidos de maneira irregular, é possível que em sendo aprovada a súmula vinculante 69 esta também tenha seus efeitos temporais modulados, na forma do art. 4 da lei $\mathrm{n}^{\circ} 11.417 / 2006$, in verbis:

Art. $4^{\mathrm{o}}$ súmula com efeito vinculante tem eficácia imediata, mas o Supremo Tribunal Federal, por decisão de 2/3 (dois terços) dos seus membros, poderá restringir os efeitos vinculantes ou decidir que só tenha eficácia a partir de outro momento, tendo em vista razões de segurança jurídica ou de excepcional interesse público.

O Supremo também pode deixar expresso que a súmula só terá aplicabilidade à concessão de incentivos posteriores a sua edição, não sendo assim aplicados aos incentivos já vigentes no momento da aprovação desta, em nome da segurança jurídica (FUNARO, 2014).

Entretanto, esta parece não ser a melhor escolha, haja vista que, sendo aprovada a súmula vinculante 69 esta apenas espelhará a jurisprudência pacífica do STF no que tange considerar que a concessão de incentivos de forma unilaterais pelos Estados é inconstitucional.

Assim, conforme já ressaltado os Estados ao concederem os benefícios à revelia do CONFAZ tem total ciência de que estão editando normas inconstitucionais, de modo que não trará a súmula nenhuma grande inovação que justifique tanto a modulação dos efeitos desta como sua aplicação futura, até porque a aprovação de uma súmula vinculante não é um processo célere, entre sua proposta, discussão e eventual aprovação se decorrem grande lapso temporal no qual os estados poderão tomar ciência desta bem como realizar as medidas que julgarem necessárias.

Funaro (2014) ressalva que seria ideal que antes da votação da PSV 69 o Congresso legislasse acerca das questôes envolvendo a concessão dos incentivos fiscais de ICMS, haja vista não ter o Supremo Tribunal Federal os função constitucional de legislador positivo para expedir normas que compatibilizem os interesses públicos e privados envolvidos na matéria.

Por mais pertinente que seja a ressalva realizada pelo autor, até o presente momento o Congresso Nacional não demonstrou vontade política necessária para resolver as questōes relacionadas à concessão irregular dos benefícios fiscais de ICMS. 
A guerra fiscal entre os estados membros da federação em relação ao ICMS • •

Conforme destacado no capítulo 3, vários são os projetos de leis que tramitam no Congresso com a finalidade de por um fim a guerra fiscal, entretanto, mesmo na crise econômica vivida pelo país não tem se tomado medidas concentras para a solução da questão.

Deste modo, não pode o STF deixar de cumprir seu papel de Guardião da Constituição, a espera do Congresso Nacional em fim resolva legislar sobre o tema.

Mais uma vez é preciso destacar que cada um dos três poderes deve utilizar de suas atribuições constitucionais para que se chegue a uma solução satisfatória ao problema da guerra fiscal.

\section{CONCLUSÃO}

Sendo a guerra fiscal um problema que traz graves consequências para federação como um todo, tais quais: vultosa renúncia de receitas, afeta a livre concorrência, geram incertezas e inseguranças jurídicas, é necessário que Três Poderes se alinhem na busca de uma solução para esta, ocorre que por trata-se de problema complexo, esta não presenta apenas uma causa muito menos uma simples solução.

Dentro do contexto de Federalismo no qual se insere o país, sendo a guerra fiscal um litígio entre os estados-membros, esta se apresenta como um ameaça ao modelo adotado, porém neste mesmo contexto a busca de alternativas para a problemática deve respeito à autonomia dos estados e do Distrito Federal, sob pena de violação a cláusula pétrea prevista no art. $60, \$ 4^{\circ}$ inciso, I da CRFB/88.

Uma das causas da guerra fiscal é atual sistemática apresentada para concessão dos incentivos. Nos moldes da Lei Complementar 24/1975, estes apenas podem ser concedidos após a aprovação unânime no CONFAZ, ocorre que se demonstra clara a dificuldade para o alcance da unanimidade exigida, o que por muitas vezes serve como justificativa para que os estados concedam os incentivos de maneira unilateral, mesmo estando plenamente cientes de que tal prática é inconstitucional.

Entretanto apenas a aprovação regular de um convênio não é garantia que este respeitará os preceitos previstos na Carta Magna. Assim destaca-se o Convênio ICMS no 42/2015, que mesmo regularmente aprovado no âmbito do CONFAZ, traz em seu texto uma série de deposições de constitucionalidade e legalidade questionáveis.

Na busca de se por um fim a guerra fiscal destaca-se vários projetos de leis em tramite junto ao Congresso Nacional. O PL n. 240 de 2006 tem como proposta o 
•- Tributação, direitos fundamentais e desenvolvimento

fim da exigência de unanimidade para a concessão dos incentivos fiscais junto ao CONFAZ, porém, assim como todo projeto de lei este necessita de vontade política para a sua aprovação, sendo que mesmo com a crise vivida no país, se encontra atualmente arquivado.

Por outro lado, a emenda constitucional 87 aprovada em 2015 se demonstra um importante instrumento no combate a guerra fiscal, esta mudou a sistemática do ICMS em relação às compras realizadas pela internet e telemarketing, de modo que à arrecadação deste será gradualmente transferida do estado de origem para o estado de destino.

A tributação no estado de destino apresenta uma série de vantagens sem paralelos com a tributação na origem, sendo que a principal delas é que a tributação no destino acaba com a força motora da guerra fiscal, ou seja, a possibilidade dos estados atraírem sociedades empresárias para o seu território com a concessão de incentivos fiscais. Assim dentre todas as propostas analisadas é que parece apresentar a maior viabilidade tanto do ponto de vista de se alcançar o objetivo quanto em relação ao respeito às regras constitucionais. Ocorre que tal proposta sofre grande rejeição dos Estados mais industrializados, já que a princípio estes perderiam em arrecadação. Porém essa visão enganosa, haja vista que o fim da guerra fiscal geraria grandes benefícios para a Federação como um todo, de modo que se os estados deixassem de conceder benefícios irregulares voltariam a possuir as receitas que vem abrindo mão ao longo de todos esses anos.

Sendo a concessão de incentivos fiscais por leis ou decretos estaduais inconstitucionais, muitas vezes o judiciário é provocado a se manifestar sobre estes.

O Supremo Tribunal Federal no julgamento das ações do controle concentrado de normas tem por reiteradas vezes declarado a inconstitucionalidade das leis e decretos concessivos de benefícios fiscais que não foram aprovadas no âmbito do CONFAZ. Entretanto, essa firme jurisprudência do Supremo não tem se demonstrado suficiente para impedir que os Estados continuem concedendo os incentivos de forma unilateral. Entre as hipóteses levantadas para explicar esta situação, estão à adoção da tese pelo STF de que a revogação da lei questionada acarreta a perda do objeto da ação, tornando-as prejudicadas e a escolha da Corte Suprema de modular os efeitos das decisōes de grande parte das ações que julgam a leis concessivas dos benefícios fiscais.

A aprovação pelo Supremo Tribunal Federal da súmula vinculante 69 que declara que qualquer isenção, incentivo, redução de alíquota ou de base de cálculo, 
A guerra fiscal entre os estados membros da federação em relação ao ICMS

crédito presumido, dispensa de pagamento ou outro benefício fiscal relativo ao ICMS concedido sem aprovação do CONFAZ é inconstitucional, seria de grande importância no enfrentamento da guerra fiscal. Porém por tratar-se apenas de um projeto, por enquanto há apenas expectativa de aprovação não gerando assim, solução concreta para o fim do problema.

\section{REFERÊNCIAS}

ABREU, Fabiano Rodrigues. Não analisar ADI porque lei foi revogada é simplório. 2007. Disponível em: <http://www.conjur.com.br/2007-abr-24/nao_analisar_adi_porque_lei_ foi_revogada_simplorio > Acesso em: 16 nov. 2016.

ABREU, Jerry Levers; DALCIN, Orlando F. Convênio ICMS 31/2016: ilegalidade ou legitimação de incentivos fiscais?. 2016. Disponível em: <http://alfonsin.com.br/ convnio- icms-31-ilegalidade-ou-convalidao> Acesso em: 10 out. 2016.

ALECRIM, Fernando. PEC 228/04: O projeto de reforma tributária do primeiro governo do Partido dos Trabalhadores (2002-2006) sob a ótica do federalismo - Parte II. 2013. Disponível em: <http://blogafresp.org.br/2013/09/03/pec-22804-o-projeto-de-reformatributaria-do-primeiro-governo-do-partido-dos-trabalhadores-2002-2006-sob-a-oticado-federalismo/> Acesso em: 2 nov. 2016.

ALEXANDRE, Ricardo. Direito tributário esquematizado. 7. ed. São Paulo: Método, 2013.

ALEXANDRINO, Marcelo; PAULO, Vicentino. Direito tributário na Constituição e no STF. 13. ed. Niterói: Impetus, 2007.

ARAUJO, Ulisses Gomes. Imposto sobre valor agregado (IVA) a guerra fiscal e o princípio do federalismo brasileiro. 2011. Disponível em: <http://www.ambito- juridico.com.br/site/ index.php?n_link=revista_artigos_leitura\&artigo_id=10746>. Acesso em: 4 out. 2016.

BARROSO, Luís Roberto. Direito constitucional contemporâneo, os conceitos fundamentais e a construção do novo modelo. 4. ed. São Paulo: Saraiva, 2012.

BATISTA, Daiane Carvalho. A guerra fiscal interestadual do ICMS no comércio eletrônico. 2012. Disponível em: <http://www.ambito- juridico.com.br/site/?n_link=revista_ artigos_leitura\&artigo_id=10993\&revista_caderno=26>. Acesso em: 27 out. 2016.

BRIGAGÃO, Gustavo. Convênio sobre depósito ou redução de benefícios fiscais de ICMS gera incertezas. 2016. Disponível em: <http://www.conjur.com.br/2016-mai-18/consultortributario-convenio-reducao-beneficios-fiscais-icms-gera-incertezas $>$. Acesso em: 10 out. 2016.

BRIGAGÃO, Paula Naves. Competência tributária. 2012. Disponível em: <http:// conteudojuridico.com.br/artigo,competencia-tributaria,36984.html>. Acesso em: 29 set. 2016. 
•• Tributação, direitos fundamentais e desenvolvimento

BULOS, Uadi Lammêgo. Curso de direito constitucional. 8. ed. São Paulo: Saraiva, 2014. CARNEIRO, Raphael Funchal. A incidência do ICMS no comércio eletrônico. 2015. Disponível em: <https://jus.com.br/artigos/38302/a-incidencia-do-icms-no-comercioeletronico>. Acesso em: 3 nov. 2016.

CARRAZA, Antônio. ICMS. São Paulo: Malheiros, 2007.

FAUSTINO, Fabrício Salema. Incentivos fiscais de ICMS ameaçados com recente disposição do CONFAZ. 2016. Disponível em: <http://www.fortes.adv.br/pt-BR/conteudo/artigos-enoticias/405/incentivos-fiscais-de-icms-ameacados-com-recente-disposicao-do-confaz. aspx>. Acesso em: 12 out. 2016.

FERRAIOLI, Renata. Implicaçôes do convênio ICMS n. 42/2016. 2016. Disponível em: <http://schneiderpugliese.com.br/blog/index.php/implicacoes-do-convenio-icmsno-422016/>. Acesso em: 13 out. 2016.

FUNARO, Hugo. Efeitos jurídicos da aprovação da proposta da Súmula Vinculante 69 pelo STF. 2014. Disponível em: <http://www.conjur.com.br/2014-out-03/hugo-funaroefeitos- juridicos-aprovacao-sumula-vinculante-69>. Acesso em: 16 nov. 2016.

GERMANO, Livia. Emenda transfere ICMS do comércio eletrônico da origem para o destino. 2015. Disponível em: <http://www.conjur.com.br/2015-abr-16/icms-comercioeletronico-mudar-origem-destino>. Acesso em: 27 out. 2016.

HARADA, Kiyoshi. Incentivos fiscais do ICMS e o Confaz. 2012. Disponível em: <http:// www.ambito- juridico.com.br/site/index.php?n_link=revista_artigos_leitura\&artigo_ $\mathrm{id}=11089>$. Acesso em: 26 out. 2016.

MAGALHAES, Michael Pedrosa. PEC 233/2008: reforma tributária, federalização do ICMS e sua (in)constitucionalidade. 2012. Disponível em: <http://www.ambitojuridico.com.br/site/index.php?n_link=revista_artigos_leitura \&artigo_id=11124>. Acesso em: 27 out. 2016.

MELO, José Eduardo Soares. ICMS teoria e prática. 12. ed. São Paulo: Dialética, 2012.

PAES, Nelson Leitão. A implantação do princípio do destino na cobrança do ICMS e suas implicaçôes dinâmicas sobre os Estados. 2009. Disponível em: <http://www.scielo.br/scielo. php?script=sci_arttext $\&$ pid=S0034-71402009000300003>. Acesso em: 26 out. 2016.

PAUSEN, Leandro; MELLO, José Eduardo. Impostos Federais, Estaduais e Municipais. 7. ed. Porto Alegre: Livraria do Advogado, 2012.

PÉRES, Taynah Litaiff Isper Abrahim Carpinteiro. A ação direta de inconstitucionalidade e a perda superveniente de seu objeto. 2010. Disponível em: <http://www.ambito- juridico. com.br/site/index.php?n_link=revista_artigos_leitura\&artigo_id=8028> Acesso em: 15 nov. 2016.

SABBAG, Eduardo. Manual de direito tributário. 6. ed. São Paulo: Saraiva, 2014.

SALAMACHA, Eduardo. ICMS e Guerra Fiscal: a busca de fundamentos constitucionais para a federalização do tributo como forma de resolução do problema da guerra fiscal. 
2013. Disponível em: <http://www.boletimjuridico.com.br/doutrina/texto.asp?id=2861 > . Acesso em: 1 nov. 2016.

SALES, Claudio J. D. ICMS: a origem do problema e o destino da solução. 2013. Disponível em: <http://www.informacoesmunicipais.com.br/?pagina=detalhe_noticia\& noticia_id=40693>. Acesso em: 27 out. 2016.

BARATTO, Gedalva; LOBATO, José Roberto Soares. Fórum fiscal dos estados brasileiros cenário de reforma tributária com tributação dual sobre o consumo, 2007.

SANTOS, Alessandro Lucas. O subsistema constitucional tributário sob a ótica do federalismo cooperativo assimétrico. 2008. Disponível em: <http://www.ambito- juridico.com.br/site/ index.php?n_link=revista_artigos_leitura\&artigo_id=2647>. Acesso em: 5 out. 2016.

SERAFIN, Gabriela Pietsch. Oprincipio federativo e a autonomia dos entes federados. 2014. Disponível em: <http://www.revistadoutrina.trf4.jus.br/index.htm?http://www.revista doutrina.trf4.jus.br/artig os/edicao058/Gabriela_Serafin.html>. Acesso em: 28 set. 2016.

SILVA, José Afonso. Curso e direito constitucional positivo. 34. ed. São Paulo: Malheiros, 2011.

TORRES, Ricardo Lobo. Tratado de direito constitucional financeiro e tributário. Rio de Janeiro: Renovar, 2007. v. IV: Os tributos na constituição.

VIEIRA, Lorena. O ICMS, o incentivo fiscal e o convênio Confaz 42/2016. 2016. Disponível em: <http://www.mtostes.com.br/blog/2016/08/12/o-icms-o-incentivo-fiscal-e-o-convenio-confaz-422016/>. Acesso em: 12 out. 2016. 
